\title{
Target-Derived Neurotrophins Coordinate Transcription and Transport of Bclw to Prevent Axonal Degeneration
}

\author{
Katharina E. Cosker, ${ }^{1,2,3}$ Maria F. Pazyra-Murphy, ${ }^{1,2,3}$ Sara J. Fenstermacher, ${ }^{1,2,3}$ and Rosalind A. Segal ${ }^{1,2,3}$ \\ ${ }^{1}$ Department of Neurobiology, Harvard Medical School, Boston, Massachusetts 02115, and Departments of ${ }^{2}$ Cancer Biology and ${ }^{3}$ Pediatric Oncology, Dana- \\ Farber Cancer Institute, Boston, Massachusetts 02215
}

Establishment of neuronal circuitry depends on both formation and refinement of neural connections. During this process, targetderived neurotrophins regulate both transcription and translation to enable selective axon survival or elimination. However, it is not known whether retrograde signaling pathways that control transcription are coordinated with neurotrophin-regulated actions that transpire in the axon. Here we report that target-derived neurotrophins coordinate transcription of the antiapoptotic gene $b c l w$ with transport of $b c l w$ mRNA to the axon, and thereby prevent axonal degeneration in rat and mouse sensory neurons. We show that neurotrophin stimulation of nerve terminals elicits new $b c l w$ transcripts that are immediately transported to the axons and translated into protein. Bclw interacts with Bax and suppresses the caspase 6 apoptotic cascade that fosters axonal degeneration. The scope of $b c l w$ regulation at the levels of transcription, transport, and translation provides a mechanism whereby sustained neurotrophin stimulation can be integrated over time, so that axonal survival is restricted to neurons connected within a stable circuit.

\section{Introduction}

Formation of a working sensory nervous system relies on axonal guidance for innervation of appropriate targets and on the selective survival of neurons that are integrated into functional circuits. These critical events are regulated by neurotrophins both during development and into adulthood (Segal, 2003; Skaper, 2012). Target-derived neurotrophins initiate retrograde signaling cascades that induce transcriptional changes enabling neuronal survival (Cosker et al., 2008; Pazyra-Murphy et al., 2009; Chowdary et al., 2012), whereas lack of neurotrophin support prevents outgrowth, triggers local axonal degeneration, and eventually causes neuronal apoptosis (Luo and O'Leary, 2005). It is currently not known whether neurons are able to coordinate transcriptional events in the cell body with localized mechanisms that function within the axons to promote axon outgrowth and survival pathways.

During axonal outgrowth, neurotrophins regulate subcellular localization and translation of specific mRNAs (Yoon et al., 2009). The most extensively characterized of these is $\beta$-actin

\footnotetext{
Received Aug. 13, 2012; revised Jan. 22, 2013; accepted Feb. 6, 2013.

Author contributions: K.E.C. and R.A.S. designed research; K.E.C., M.F.P.-M., and S.J.F. performed research;K.E.C., M.F.P.-M., S.J.F., and R.A.S. analyzed data; K.E.C. and R.A.S. wrote the paper.

This work was supported by National Institutes of Health Grant R01 NS050674 to R.A.S. and Grant F31NS077620 to S.J.F., K.E.C. is a David Mahoney Fellow at Harvard Medical School and a recipient of a Neurodegenerative Disease Pilot Study grant from Massachusetts General Hospital Neurology Clinical Trials Unit and Harvard NeuroDiscovery Center. S.J.F. is a Victoria Quan Fellow at Harvard Medical School. Confocal microscopy imaging was performed at the Harvard NeuroDiscovery Center Optical Imaging Program. We thank Stephanie Courchesne for help in generating in vivo samples, Jose Alfaro and Emily Chadwick for assistance with $b \mathrm{clw}^{-/-}$mice, Eugene Vaios for assistance with designing probes for ISH, and the members of the R.A.A. laboratory and the Qiufu Ma laboratory for helpful advice. The authors declare no competing financial interests.

Correspondence should be addressed to Dr. Rosalind A. Segal, Departments of Cancer Biology and Pediatric Oncology, Dana-Farber Cancer Institute, 450 Brookline Avenue, Boston, MA 02215. E-mail: Rosalind_segal@dfci.harvard.edu.

DOI:10.1523/JNEUROSCI.3862-12.2013

Copyright $\odot 2013$ the authors $\quad 0270-6474 / 13 / 335195-13 \$ 15.00 / 0$
}

mRNA, which is both targeted to axons and locally translated there in response to neurotrophins to facilitate growth cone motility and neurotrophin-dependent axon guidance (Zhang et al., 1999; Zhang et al., 2001; Willis et al., 2005; Yao et al., 2006; Willis et al., 2007). It has been proposed that local protein synthesis of $\beta$-actin allows axonal turning responses to occur rapidly and independently of the remote cell body.

More recently it has been reported that mRNA localization and local translation may also play a role in neurotrophindependent axonal survival. One such mRNA is Impa1, which is targeted to sympathetic neuron axons and locally translated in response to nerve growth factor (NGF) stimulation of distal axons (Andreassi et al., 2010). The Impal gene product is critical for synthesizing membrane lipids and thereby promotes axonal maintenance. Similarly, local synthesis of Lamin B2 is critical for axon maintenance in Xenopus retinal ganglion cell axons (Yoon et al., 2012). It is currently unknown whether local protein synthesis enables axonal survival to be regulated independently of the cell body or whether neurotrophins coordinate survival pathways in the cell body and axons.

$\mathrm{Bcl} 2$ family members are critical determinants of neurotrophin survival responses. In sensory neurons, $\mathrm{Bclw}(\mathrm{Bcl} 2 \mathrm{l} 2)$ is the only antiapoptotic $\mathrm{Bcl} 2$ family member selectively regulated by target-derived neurotrophins (Pazyra-Murphy et al., 2009; Courchesne et al., 2011). Furthermore, Bclw is the Bcl2 family member that exhibits substantial protein expression in axons and prevents axonal degeneration in vivo (Courchesne et al., 2011). Here we show that mRNA encoding $b c l w$ is present in peripheral axons as well as in cell bodies of sensory neurons, and neurotrophin stimulation of distal axons increases levels of $b c l w$ mRNAs in both locations. Our studies indicate that a retrograde neurotrophin signaling cascade leads to transcription of bclw mRNA, which is immediately transported back to the stimulated axons. 
There, $b c l w$ is translated in response to continuous neurotrophin exposure and thereby suppresses axon degeneration mediated by Bax and caspase6. Thus, target-derived neurotrophins coordinate transcription, mRNA transport, and translation in space and time to promote neuronal survival of cell bodies and axons.

\section{Materials and Methods}

Microfluidic chambers. Cover glass (Fisherband Microscope Cover Glass; $24 \times 40-1$ ) was coated with $0.25 \mathrm{mg} / \mathrm{ml}$ poly-M-lysine in HBSS overnight at room temperature. After washing with $\mathrm{ddH}_{2} \mathrm{O}$, the microfluidic chamber (Xona Microfluidics) was attached to the cover glass. Laminin (10 $\mu \mathrm{g} / \mathrm{ml}$ ) was added to each channel at $37^{\circ} \mathrm{C}$ for $3 \mathrm{~h}$. Dorsal root ganglia (DRG) from embryonic day 15 (E15) rats of either sex were dissected, trypsinized, and plated directly into the channel at 100,000 cells/microfluidic chamber in $5 \mu \mathrm{l}$ of media (DMEM with $5 \%$ horse serum, $1 \%$ penicillin-streptomycin, and $0.3 \mu \mathrm{M}$ cytosine arabinoside [AraC], and 50 $\mathrm{ng} / \mathrm{ml} \mathrm{NGF}+$ BDNF; PeproTech). After allowing cells to attach for 10 min, $100 \mu \mathrm{l}$ of media with $50 \mathrm{ng} / \mathrm{ml} \mathrm{NGF}+$ BDNF was added to cell body wells, and $100 \mu \mathrm{l}$ of media with $100 \mathrm{ng} / \mathrm{ml} \mathrm{NGF}+$ BDNF to axonal wells. Media was changed daily, removing AraC, and cells were fixed after $4 \mathrm{~d}$ in culture with ice-cold $\mathrm{MeOH}$ for $2 \mathrm{~min}$ and 4\% PFA for $20 \mathrm{~min}$.

FISH. DRGs from E15 rats of either sex were cultured in microfluidic chambers as described above. Cells were permeabilized in $0.5 \%$ Triton $\mathrm{X}-100$ for $10 \mathrm{~min}$ and refixed in 4\% PFA for $5 \mathrm{~min}$. Cells were acetylated in $0.25 \%$ acetic anhydride in $0.1 \mathrm{~m}$ triethanolamine for $10 \mathrm{~min}$ and washed in PBS. Neurons were prehybridized for $1 \mathrm{~h}$, before being incubated in $1 \mu \mathrm{g} / \mathrm{ml}$ probe at a final concentration of $4 \%$ dextran sulfate overnight at $65^{\circ} \mathrm{C}$. Cultures were washed in $0.2 \times$ saline-sodium citrate at $65^{\circ} \mathrm{C}$, cooled down, and equilibrated in TNT buffer ( $100 \mathrm{~mm}$ Tris, $\mathrm{pH} 7.5$, $150 \mathrm{~mm} \mathrm{NaCl}, 0.05 \%$ Tween) for $5 \mathrm{~min}$. Cells were incubated in blocking buffer (100 mM Tris, pH 7.5, $150 \mathrm{~mm} \mathrm{NaCl}, 0.5 \%$ blocking reagent) for $1 \mathrm{~h}$ and anti-digoxigenin-POD (1:500) and mouse anti-Tuj1 (1:400; Covance) in blocking buffer overnight at $4^{\circ} \mathrm{C}$. Cultures were washed with TNT buffer and incubated in biotin-tyramide (1:50; PerkinElmer) in amplification plus solution for $8 \mathrm{~min}$. After washing in TNT, cells were incubated with 546-Strepdavidin and goat anti-mouse 488 in blocking buffer for $1 \mathrm{~h}$ at room temperature. Cells were washed with TNT and mounted. Images were obtained using NIS Imaging software and a $60 \times$ oil objective.

In situ hybridization. Probes for $b c l w, \beta$-actin, and $\gamma$-actin were amplified with gene-specific sets of PCR primers and cDNA templates prepared from P0 rat brain. Digoxigenin-labeled riboprobes were generated with digoxigenin-RNA labeling mixture (Roche) and T7 RNA polymerase. Whole DRG with central and peripheral nerves were dissected from P0 rats of either sex and fixed overnight in 4\% PFA in DEPC PBS. After fixation, embryos were dehydrated stepwise into $100 \% \mathrm{MeOH}$. Before hybridization, DRGs were rehydrated, refixed, and prehybridized in hybridization buffer for $1 \mathrm{~h}$ at $65^{\circ} \mathrm{C}$. Prehybridization buffer was replaced with hybridization buffer containing $1.5 \mu \mathrm{g} / \mathrm{ml}$ probe and hybridized overnight at $65^{\circ} \mathrm{C}$. After washes, DRGs were blocked in TBST $+10 \%$ lamb serum for $2 \mathrm{~h}$ at room temperature, then incubated in TBST $+10 \%$ lamb serum containing $1 / 2000$ dilution of alkaline phosphataseconjugated sheep anti-digoxigenin Fab fragments overnight at $4^{\circ} \mathrm{C}$. After washing in TBST, and alkaline phosphatase buffer, DRGs were incubated in BM Purple (BMB/Roche) until signal was detected. The reaction was stopped by washing in PBST/5 mm EDTA, DRGs were postfixed in $4 \%$ PFA for $24 \mathrm{~h}$, washed and mounted.

Cell cultures. Compartmented chamber cultures (Campenot cultures) were prepared as previously described (Heerssen et al., 2004; PazyraMurphy and Segal, 2008). Briefly, DRGs from embryonic day 15 (E15) rats or E13 $b c l w^{+/+}$and $b c l w^{-1-}$ mice of either sex were dissected, trypsinized, and plated in the center compartment of a Teflon divider (Camp10; Tyler Research) (Campenot, 1982). Cultures were maintained in media consisting of DMEM with $5 \%$ horse serum, $1 \%$ penicillinstreptomycin, and $0.3 \mu \mathrm{M} \mathrm{AraC}$ at $37^{\circ} \mathrm{C}, 7.5 \% \mathrm{CO}_{2}$; BDNF + NGF (PeproTech) were added to the cell body compartment at a concentration of $10 \mathrm{ng} / \mathrm{ml}$ and to the axon compartment at a concentration of $100 \mathrm{ng} / \mathrm{ml}$ for $2 \mathrm{~d}$. On day 3, media was replaced and the $\mathrm{AraC}$ was omitted. On day
5 , neurotrophins were removed from the cell body compartment and reduced to $1 \mathrm{ng} / \mathrm{ml}$ in axon compartments for 3-7 d. For each experiment, neurons were starved for $2 \mathrm{~h}$ in serum and neurotrophin-free media, and then vehicle control (100 ng/ml BSA in PBS) or neurotrophins $(100 \mathrm{ng} / \mathrm{ml} \mathrm{BDNF}+\mathrm{NGF})$ were applied to distal axons or cell body compartments for the indicated time. Mass cultures consisting of $3 \times 10^{5}$ DRG neurons were grown on laminin-coated 35 cultures dishes (Nunc) in neurotrophin-enriched $(100 \mathrm{ng} / \mathrm{ml} \mathrm{NGF}+\mathrm{BDNF})$ media with 0.3 $\mu \mathrm{g} / \mathrm{ml}$ AraC.

$q R T-P C R$. RNA was extracted from DRG neurons in compartmented chamber cultures using Trizol (Invitrogen) according to the manufacturer's protocol. Reverse transcription was performed using the cDNA archive kit (Applied Biosystems) according to the manufacturer's specifications. Quantitative real-time RT-PCR was performed using TaqMan gene expression assays (Applied Biosystems) to assess the expression of $c$-fos (Rn02105452_s1), bclw (Rn00821025_g1), $\beta$-actin (Rn00667869_m1), and $\gamma$-actin (Rn01470738_g1). For each sample, data were normalized to the expression level of gapdh (Applied Biosystems).

Western blotting. For analysis of Bclw protein in DRG cell bodies and distal axons, E15 rat DRGs were grown in compartmented chamber cultures as described above. Cells and axons were lysed in nonionic detergent, and protein lysates were separated by $4-12 \%$ SDS-PAGE and blotted with the following antibodies: anti-pTrk (1:1000; pY-490) (Segal et al., 1996), anti-phospho Erk1/2 (1:1000; Cell Signaling Technology), anti-pan-actin (1:1000; Cell Signaling Technology), anti-Bclw (1:200; Stressgen), anti-His (1:1000; Novagen), anti-Bax (1:1000; Cell Signaling Technology), and anti-GAPDH (1:1000; Cell Signaling Technology). Bands were visualized with secondary antibodies conjugated to HRP (1:10,000; Bio-Rad) and SuperSignal chemiluminescent substrate kit. Using National Institutes of Health ImageJ software, protein levels were quantified and levels of protein were normalized to GAPDH.

$m R N A$ stability. E15 rat DRG neurons were grown in mass cultures as described. After $2 \mathrm{~d}$ in culture, 4-thiouridine nucleoside (20 $\mu \mathrm{M}$; Sigma) was added to cultures for $24 \mathrm{~h}$ for mRNA labeling. Total RNA was extracted at 0,4 , and $8 \mathrm{~h}$ after 4 -thiouridine removal. Total RNA $(10 \mu \mathrm{l})$ was biotinylated with EZ-Link HPDP-Biotin (Pierce) for $3 \mathrm{~h}$ at room temperature in the dark. Labeled RNA was precipitated and washed with 75\% EtOH. Biotinylated mRNA was purified using Dynabeads MyOne Streptavidin C1 (Invitrogen), blocked with $10 \mathrm{mg} / \mathrm{ml}$ yeast tRNA for $1 \mathrm{~h}$ at room temperature. Biotinylated RNA was added to the beads $(10 \mu \mathrm{l}$ RNA to $100 \mu \mathrm{l}$ beads) and incubated for $15 \mathrm{~min}$ at room temperature. Beads were collected, washed 3 times with buffer $(1 \mathrm{M} \mathrm{NaCl}, 10 \mathrm{~mm}$ EDTA, and $100 \mathrm{~mm}$ Tris- $\mathrm{HCl}, \mathrm{pH}$ 7.4, in RNase-free $\mathrm{H}_{2} \mathrm{O}$ ), and bound RNA was eluted by addition of $5 \% 2$-mercaptoethanol. The eluted thiolated RNA was precipitated with 2-propanol, spun, washed with $75 \% \mathrm{EtOH}$, spun, and resuspended in $20 \mu \mathrm{l}$ RNase-free $\mathrm{H}_{2} \mathrm{O}$. Reverse transcription was performed using the cDNA archive kit (Applied Biosystems), according to manufacturer's specifications for analysis by qRT-PCR.

Drug treatment. Distal axons and cell bodies of DRG neurons grown in compartmented chamber cultures were treated either with $200 \mathrm{~nm}$ K252A (Calbiochem), $10 \mu \mathrm{M}$ U0126 (Calbiochem), $20 \mu \mathrm{M}$ actinomycin $\mathrm{D}$ (actD), $10 \mu \mathrm{g} / \mathrm{ml}$ cycloheximide (Calbiochem), $10 \mu \mathrm{M}$ anisomycin (Sigma), 500 nm ABT-263 (Selleck Chemicals) or DMSO vehicle control. Drugs were applied $10 \mathrm{~min}$ before neurotrophin stimulation or throughout the duration of neurotrophin deprivation.

4-Thiouridine labeling. E15 rat DRGs were grown in compartmented chamber cultures as described. For pulse-labeling experiments, 4-thiouridine nucleoside ( $20 \mu \mathrm{M}$; Sigma) was added to cell body compartments during $2 \mathrm{~h}$ of distal axon neurotrophin (NT) stimulation, and then removed for an additional $2 \mathrm{~h}$ of NT stimulation. For control experiments, 4-thiouridine nucleoside was added to cell body compartments $24 \mathrm{~h}$ before NT stimulation, during which time it was removed. After NT stimulation, total RNA was extracted from cell bodies and distal axons using Trizol (Invitrogen). Total RNA (10 $\mu \mathrm{l})$ was biotinylated and precipitated as described. A $3 \mu \mathrm{l}$ RNA sample was removed and reverse transcription was performed using the cDNA archive kit (Applied Biosystems) to check for neurotrophin induction of total-biotinylated mRNA by qRT-PCR. Total biotinylated mRNA was captured on Dyna- 
beads MyOne Streptavidin C1 (Invitrogen), and purified 4-thiouridine biotinylated RNA was eluted as described. The eluted thiolated RNA was precipitated with 2-propanol, spun, washed with $75 \% \mathrm{EtOH}$, spun, and resuspended in $20 \mu \mathrm{l}$ RNase-free $\mathrm{H}_{2} \mathrm{O}$. Reverse transcription was performed using the cDNA archive kit (Applied Biosystems), according to manufacturer's specifications for analysis by qRT-PCR.

His pulldown of recombinant Bclw protein. E15 rat DRGs were grown in mass cultures as described. After $2 \mathrm{~d}$ in culture, recombinant His-tagged Bclw protein was introduced using Chariot reagent. Cells were lysed in nonionic detergent and transferred onto Dynabeads for His-Tag Isolation \& Pulldown (Invitrogen) according to the manufacturer's instructions. Input and pulldown were analyzed by Western blotting.

Axonal degeneration assay. E15 rat DRGs were grown in compartmented chamber cultures. After $6 \mathrm{~d}$ in culture, the cell body compartment was maintained in $10 \mathrm{ng} / \mathrm{ml} \mathrm{NGF}+\mathrm{BDNF}$, and the axonal compartment was starved in DMEM alone for $10 \mathrm{~h}$ before fixation and staining. Compartmented chamber cultures were fixed in ice-cold $\mathrm{MeOH}$ for $2 \mathrm{~min}$ and 4\% PFA for 20 min, blocked in 2\% BSA and $0.5 \%$ Triton X-100 for $1 \mathrm{~h}$ at room temperature, incubated with mouse antiTuj1 (1:400, Covance) overnight at $4^{\circ} \mathrm{C}$ and then with goat anti-mouse AlexaFluor-488 (1:1000; Invitrogen) for $1 \mathrm{~h}$ at room temperature, and counterstained with DAPI. Images of distal axons were obtained using a $40 \times$ objective and NIS Elements software. To quantify axonal degeneration, we used the method described by Sasaki et al. (2009). Images were binarized so that axonal areas were converted to black and background areas were converted to white. To detect fragmented (degenerating) axons, the particle analyzer function of National Institutes of Health ImageJ software was used to determine the area of the fragments (size, 5-1000 pixels). The degeneration index was then calculated as the ratio of the area of fragmented axons over the total axon area.

Caspase6 immunostaining. For in vitro analysis, compartmented chamber cultures were fixed in ice-cold $\mathrm{MeOH}$ for $2 \mathrm{~min}$ and then in $4 \%$ PFA for $20 \mathrm{~min}$. Cultures were blocked in 5\% normal goat serum and $0.1 \%$ Triton-X for $1 \mathrm{~h}$. Cultures were incubated overnight at $4^{\circ} \mathrm{C}$ in primary antibody (1:100 anti-Active/Cleaved Caspase6; Imogene; and 1:400 anti-Tuj 1; Covance) followed by incubation in secondary antibody (1:1000 AlexaFluor-546 and AlexaFluor-488; Invitrogen) for $1 \mathrm{~h}$ at room temperature, and counterstained with DAPI. Active caspase6 was quantified using ImageJ software, taking the average of the mean fluorescence within each axon as defined by Tuj1 staining.

Protein introduction. Recombinant His-tagged Bclw (R\&D Systems) was introduced into E15 DRG sensory neurons using the Chariot protein transfection system (Active Motif). $\beta$-Galactosidase protein was used as a control. Bclw or $\beta$-galactosidase $(1 \mu \mathrm{g} / \mu \mathrm{l})$ was introduced into mass cultures using $6 \mu \mathrm{l}$ of Chariot or into the cell body or into distal axon compartments of compartmented chamber cultures by using $2 \mu \mathrm{l}$ of Chariot reagent.

Footpad innervation. $b c l w^{+1+}$ and $b c l w^{-1-}$ animals of either sex were killed with isoflurane, and then footpad tissue from hindpaws was removed, fixed overnight in Zamboni's fixative at $4^{\circ} \mathrm{C}$, and cyropreserved in $30 \%$ sucrose overnight at $4^{\circ} \mathrm{C}$. Footpads were frozen, and $30 \mu \mathrm{m}$ floating sections were prepared. Tissue sections were blocked in $10 \%$ normal goat serum and $0.1 \%$ Triton X-100 in PBS for $1 \mathrm{~h}$ at room temperature and then incubated in anti-tuj1 (1:400; Millipore Bioscience Research Reagents) or anti-substance P (1:100; R\&D Systems) and antiActive/Cleaved Caspase6 (1:100; Imgenex) overnight at $4^{\circ} \mathrm{C}$. Sections were then incubated in goat anti-mouse AlexaFluor-488 (1:200; Invitrogen) and goat anti-rabbit AlexaFluor-568 (1:200; Invitrogen) and DAPI (1:1000) for $2 \mathrm{~h}$ at room temperature and mounted on gelatin-coated slides. Confocal images were obtained using a Carl Zeiss LSM 510 META upright confocal microscope, with a $40 \times$ oil objective. Caspase 6 staining was quantified using ImageJ software, taking the average of the mean fluorescence per pixel within each $z$-stack of an axon outlined by Tuj1 or substance $P$ staining.

Statistics. Data are expressed as mean \pm SEM. To assess statistical significance, data were analyzed by unpaired two-tailed Student's $t$ test or by $z$ test for a difference from 1 . For multiple comparisons, data were analyzed by one-way ANOVA with post hoc Bonferroni or Dunnett correction. Significance was placed at $p<0.05$ unless otherwise indicated.
Animal use. Timed pregnant rats were purchased from Charles River. $b c l w^{-1-}$ mice were a generous gift from Grant MacGregor (University of California, Irvine, CA) (Ross et al., 1998). Genotyping for the wild-type $b c l w$ gene and/or lacZ gene were performed by Transnetyx using the Bclw targeting sequenceGCTCTGAACCTCCCCATGACTTAAATCCGTTGCTCTTT CT-TGGCCCTGCCCAGTGCCTCTGAGCATTTCACCTATCTCAGGA GCand thelacZsequence CGATCGTAATCACCCGAGTGTGATCATCTG GTCGCTGGGGAATGAGTCAGGCCACG-G. All experimental procedures were done in accordance with the National Institutes of Health guidelines and were approved by the Dana-Farber Cancer Institutional Animal Care and Use Committee.

\section{Results \\ Target-derived neurotrophins regulate axonal levels of bclw mRNA}

Bclw promotes neurotrophin-dependent maintenance of sensory nerve fibers (Courchesne et al., 2011). As Bclw protein is expressed in axons, we asked whether bclw mRNA is also localized to axons of sensory neurons. FISH (Hafezparast et al., 2003) of cultured DRG neurons in microfluidic chambers (Fig. 1A) demonstrates the presence of $b c l w$ transcripts in axons as well as cell bodies (Fig. $1 B$ ). This pattern is similar to $\beta$-actin mRNA, which is known to be localized to axons, and in contrast to $\gamma$-actin mRNA, which is restricted to cell bodies (Willis et al., 2007) (Fig. $1 B)$. By qRT-PCR from DRG neurons grown in compartmented chamber cultures, $b c l w$ mRNA shows a relative enrichment in axonal compartments compared with cell body compartments (Fig. 1C). Similarly, ISH in whole DRG and associated peripheral nerves demonstrates the presence of $b c l w$ and $\beta$-actin transcripts in cell bodies and in peripheral nerves, consistent with expression of $b c l w$ mRNA in axons (Fig. $1 D, E$ ). Together, these data indicate that $b c l w$ mRNA, like $\beta$-actin mRNA, is localized to axons of developing sensory neurons. In vivo, the central and peripheral axons of DRG neurons can be clearly distinguished from one another. We find that $b c l w$ mRNA is clearly evident in cell bodies and peripheral nerves but is barely detectable in the central projections (Fig. $1 F$ ). In contrast, $\beta$-actin mRNA shows a high level of expression in both central and peripheral nerves (Fig. $1 F$ ). This suggests that, in vivo, bclw mRNA is primarily localized to peripherally extending axons that encounter target-derived neurotrophins.

As a retrograde response gene, $b c l w$ transcription is selectively induced in response to distal axon neurotrophin stimulation (Pazyra-Murphy et al., 2009; Courchesne et al., 2011). Using compartmented chamber cultures, we find that selective distal axon neurotrophin stimulation for $2 \mathrm{~h}$ not only increases $b c l w$ levels in the cell bodies but also increases $b c l w$ mRNA levels in axon compartments (Fig. 2A). In contrast, $b c l w$ mRNA levels do not change in either cell bodies or distal axons in response to neurotrophin stimulation of cell bodies (Fig. 2B). In these experiments, the transcription factor $c$-fos serves as a critical control. Expression of $c$-fos is induced in cell bodies in response to neurotrophin stimulation of either cell bodies or distal axons, and so provides a measure of successful stimulation, whereas $c$-fos mRNA levels in axons are barely detectable and do not change with neurotrophin stimulation (Fig. $2 A, B$ ). In these experiments $\beta$-actin serves as a positive control, as neurotrophins induce transport of $\beta$-actin mRNA from cell bodies to axons (Willis et al., 2007), and so levels of $\beta$-actin mRNA in axons increase in response to neurotrophin stimulation of distal axons (Fig. 2A). Interestingly, cell body stimulation also increases $\beta$-actin mRNA levels in distal axons (Fig. 2B).

Neurotrophin-dependent increases in axonal $b c l w$ mRNA levels could be the result of transport of mRNA from the cell body or 
A

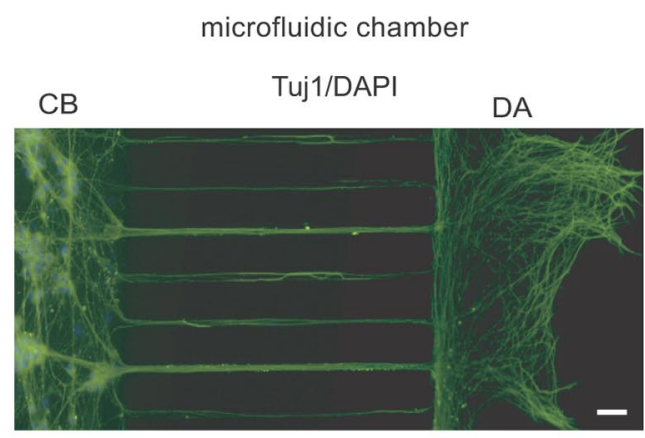

C

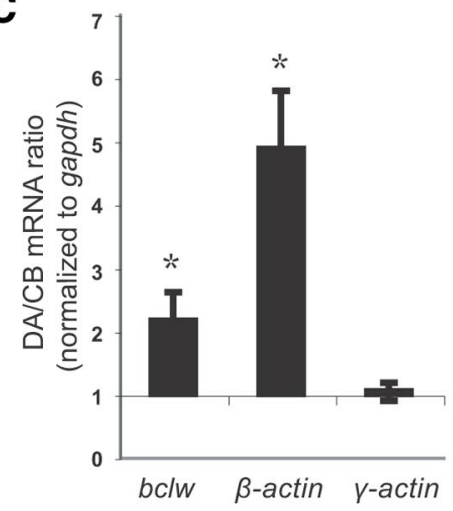

D
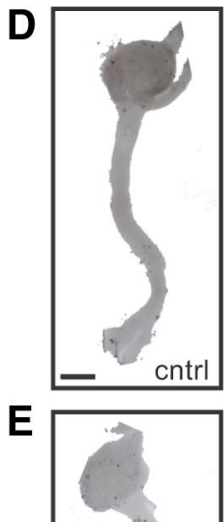
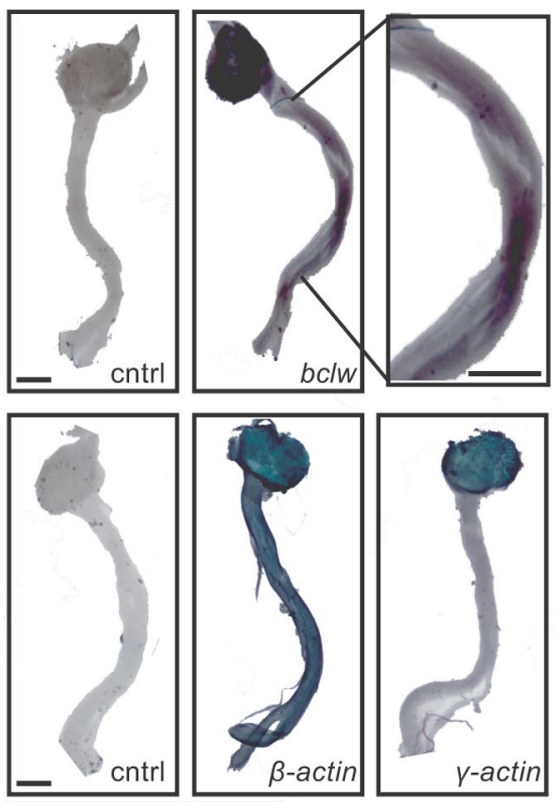

cntrl

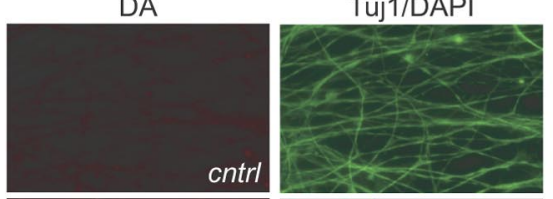

$\mathbf{F}$
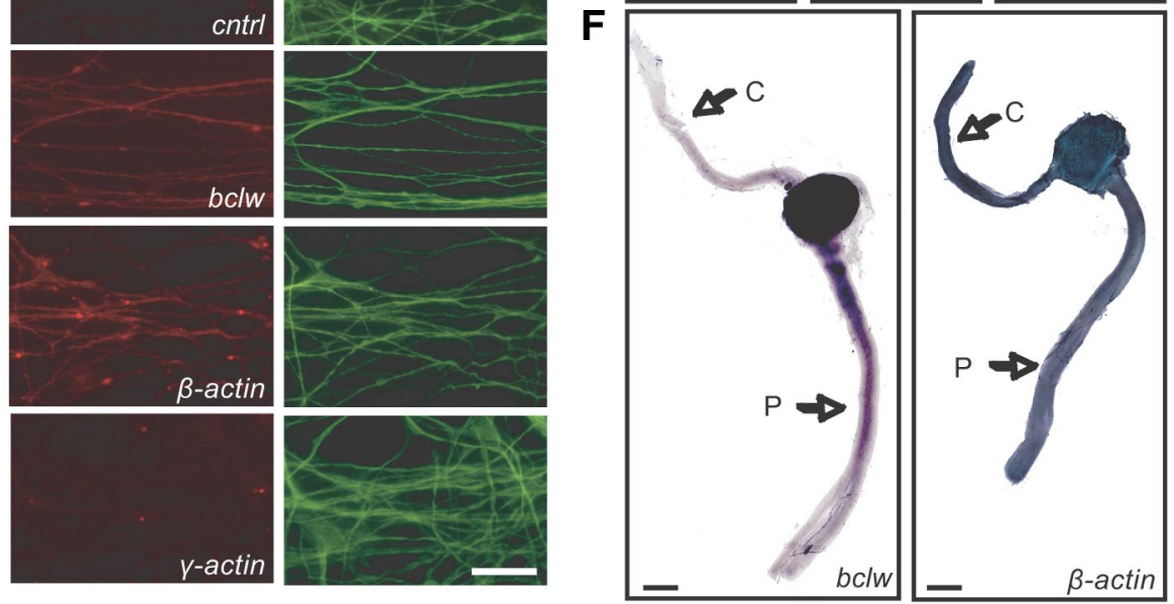

Figure 1. BclwmRNA is localized in peripheral axons of sensory neurons. $A$, Tuj 1 immunostaining (green) and DAPI staining of E15 DRG neurons grown in microfluidic chambers. Scale bar, $60 \mu \mathrm{m}$. $B$, FISH assay of $b c l w, \beta$-actin, and $\gamma$-actin mRNA (red) in cell body (CB) and distal axon (DA) compartments. Counterstained images show Tuj1 antibody (green) and DAPI. Scale bars, $20 \mu \mathrm{m}$. C, mRNA from CB and DA of E15 DRG neurons grown in compartmented chamber cultures for $b c l w, \beta$-actin, and $\gamma$-actin analyzed by qRT-PCR. Data are presented as the mean $+S E M$ of DA mRNA/CB mRNA ratio, normalized to gapdh mRNA. Statistical analysis by $z$ test. ${ }^{*} p<0.05$ for a difference from $1 . n=7$. D, ISH in PO DRGs and peripheral nerves with antisense $b c / w$ and nonsense control probes. Scale bars, $500 \mu \mathrm{m}$. E, ISH in PO DRGs and peripheral nerve with antisense $\beta$-actin and $\gamma$-actin and nonsense control probes. Scale bar, $500 \mu \mathrm{m}$. F, ISH in PO DRGS and associated central (C) and peripheral (P) nerve with antisense bclw and $\beta$-actin probes. Scale bar, $500 \mu \mathrm{m}$.

could reflect an increase in mRNA stability within the axon. To distinguish these possibilities, we removed the cell bodies of sensory neurons grown in compartmented chamber cultures, then stimulated distal axons with neurotrophins for $2 \mathrm{~h}$. In these experiments, axons are still responsive to neurotrophins in the absence of cell bodies for at least $6 \mathrm{~h}$ after cell body removal, as shown by activation of Trk and Erk (Fig. 2D). After removal of cell bodies, increases in axonal $b c l w$ and $\beta$-actin mRNA are abrogated, indicating that increased axonal mRNA is not simply the result of local events that cause neurotrophin-dependent stabilization of $b c l w$ mRNA in axons (Fig. $2 C$ ). To investigate further whether neurotrophins regulate $b c l w$ mRNA stability, we studied mRNA decay kinetics. We labeled endogenous mRNA with 4-thiouridine for $24 \mathrm{~h}$ (Zeiner et al., 2008), then removed 4-thiouridine and measured changes in levels of labeled mRNA over time by qRT-PCR. Half-life was quantified by obtaining the decay rate constant from the line of best fit of a semilogarithmic plot of mRNA concentration (Chen et al., 2008). The half-life of $b c l w$ is $5 \mathrm{~h}$, consistent with prior studies in non-neuronal cells
(Danckwardt et al., 2011) and the relative decay kinetics of bclw mRNA over $8 \mathrm{~h}$ are unaffected by neurotrophins (Fig. $2 E$ ). We compared $b c l w$ with $\beta$-actin mRNA, which shows similar decay rates to previous studies (Leclerc et al., 2002), and found no significant difference in decay kinetics between $\beta$-actin and bclw mRNA. Half-life measurements for $c$-fos and gapdh mRNA, which are respectively rapidly and very slowly degraded, served as controls (Guhaniyogi and Brewer, 2001). Together, these data indicate a mechanism whereby neurotrophins induce transport of $b c l w$ mRNA from cell bodies to axons, with no effect on mRNA stability.

We analyzed the temporal relationship between increases in cell body mRNA levels and those seen in the axon after axonal neurotrophin stimulation of axons. Increased levels of $b c l w$ mRNA are seen in the cell body after 30 min of stimulation (Fig. $3 A$ ). These data are in line with the time course seen for other early transcriptional changes induced by neurotrophin stimulation of these cultures (Riccio et al., 1997; Watson et al., 1999). Intriguingly, there is no increase in $b c l w$ mRNA levels in distal 
A

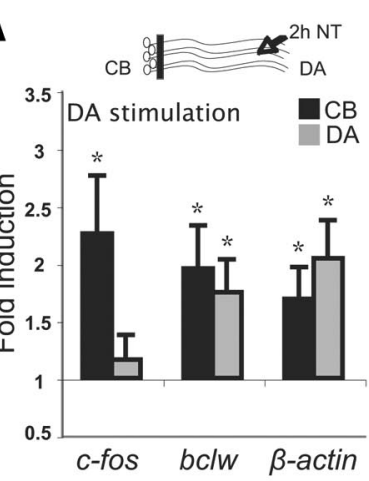

C

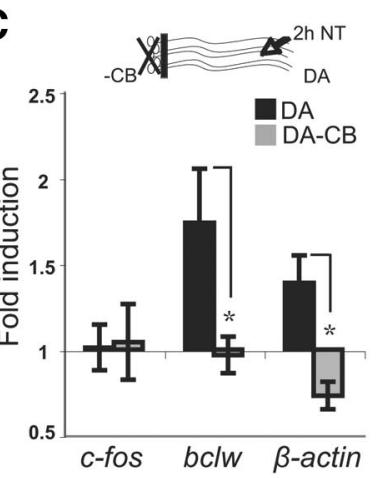

E

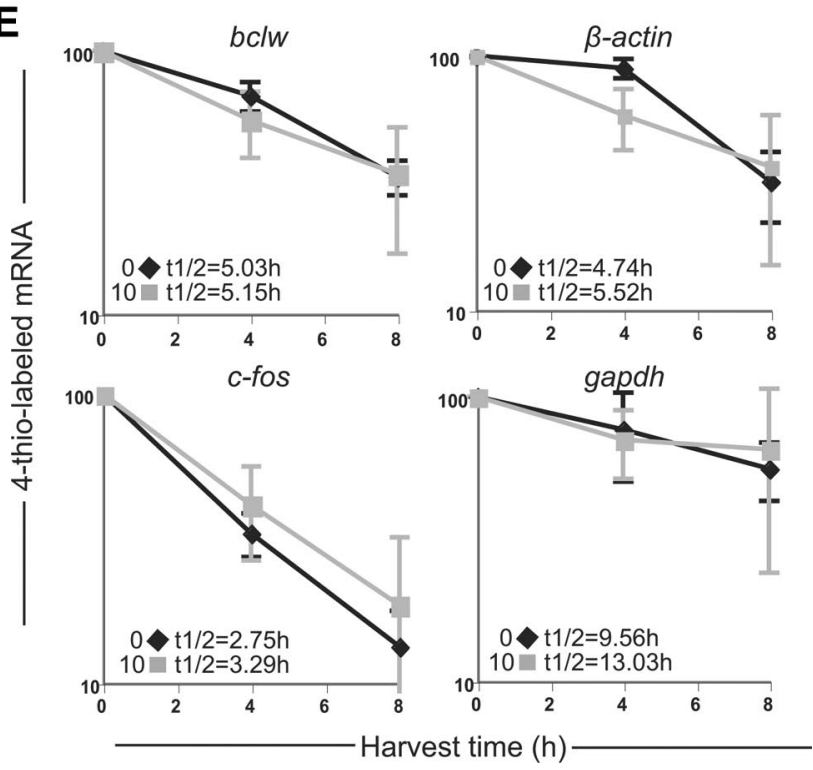

Figure 2. Neurotrophins regulate $b c / w$ mRNA in cell bodies and distal axons. $A$, Compartmented chamber cultures were stimulated with neurotrophins (NT; $100 \mathrm{ng} / \mathrm{ml} \mathrm{NGF}+\mathrm{BDNF}$ ) at distal axons (DA) for $2 \mathrm{~h}$. Bdw and $\beta$-actin mRNA is upregulated in cell bodies (CB) and distal axons (DA). Expression is compared with neurons treated with vehicle ( $100 \mathrm{ng} / \mathrm{ml} B S A)$. Fold induction of $c$-fos $m R N A$ is a control. All results represent the mean + SEM. ${ }^{*} p<0.05$, difference from 1 ( $z$ test); $n=8 . \boldsymbol{B}$, Expression of $c$-fos, bclw, and $\beta$-actin mRNA in CB and DA in responseto $2 \mathrm{hNT}$ stimulation of $C B$. ${ }^{*} p<$ 0.05 , difference from 1 (ztest); $n=8$. C, Severing of cell bodies during NT stimulation of DA prevents increases in $b c$ w wand $\beta$-actin mRNA in DA. D, Cell bodies were severed from axons and DAlysates were blotted with $p$ Trk and $p$ Erk $1 / 2$. After $6 \mathrm{~h}$, axons still respond to NT stimulation. Pan-actin was used as a loading control. E, Decay kinetics of $b c l w$ and $\beta$-actin mRNA and control mRNAs c-fos and gapdh in the absence $(0)$ or presence $(10)$ of NT. Data are presented as amount of 4-thio-labeled mRNA, normalized to no thiol control; $n=5$.

axons until $1 \mathrm{~h}$ after stimulation (Fig. 3A). This temporal pattern suggests that a retrograde signal must first reach the cell body and increase transcription of $b c l w$ mRNA, before $b c l w$ mRNA in the distal axon can be affected. This is strikingly different from
A
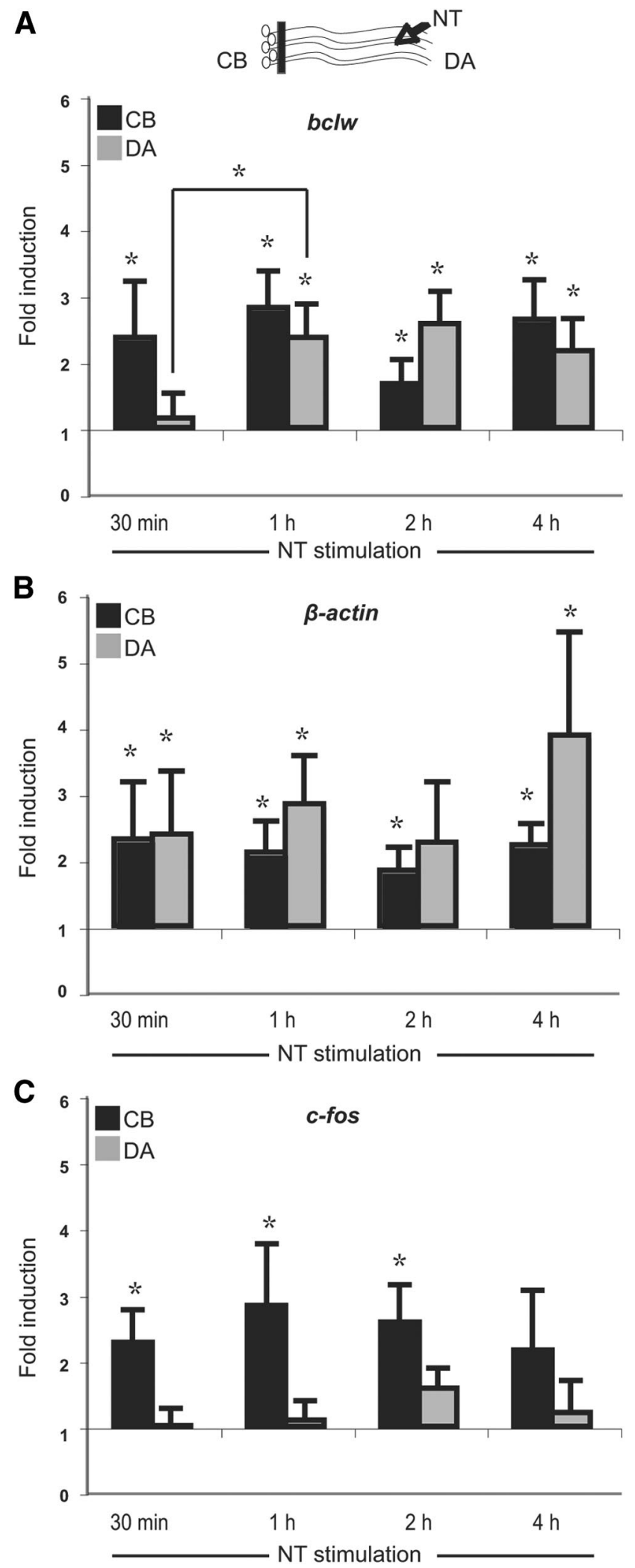

Figure 3. Bdw mRNA increases in cell bodies before distal axons. Compartmented chamber cultures were stimulated with neurotrophins (NT) at distal axons (DA) for $30 \mathrm{~min}, 1 \mathrm{~h}, 2 \mathrm{~h}$, and $4 \mathrm{~h}$. A, After 30 min NTs induce bclw mRNA expression increases only in cell bodies (CB). All data show mean + SEM. ${ }^{*} p<0.05,30$ min versus $1 \mathrm{~h}$ (Student's test); $n=10$. At 1,2 , and $4 \mathrm{~h}, b c / w$ mRNA increases in both $C B$ and DA. ${ }^{*} p<0.05$, difference from 1 ( $z$ test); $n=10$. $B$, Expression of $\beta$-actin mRNA increases at 30 min, $1 \mathrm{~h}, 2 \mathrm{~h}$, and $4 \mathrm{~h}$ both in $\left(B\right.$ and DA. ${ }^{*} p<0.05$, difference from 1 ( $z$ test); $n=10$. C, Expression of $c$-fos mRNA is induced only in CB. ${ }^{*} p<0.05$, difference from 1 (z test); $n=10$. 
$\beta$-actin mRNA, where there is a concomitant increase in mRNA levels in both cell bodies and distal axons by $30 \mathrm{~min}$ (Fig. $3 B)$. At each time point, $c$-fos induction serves as a control for successful stimulation (Fig. 3C).

Induction of $b c l w$ mRNA in cell bodies by neurotrophin stimulation of distal axons depends on a retrograde Trk-Erk5 pathway culminating in Mef2D-dependent transcription of $b c l w$ (Pazyra-Murphy et al., 2009). Because bclw mRNA levels are increased in axons after cell bodies, we asked whether axonal levels of $b c l w$ mRNA are also regulated through retrograde Trk-Erk signaling or through a distinct regulatory mechanism. Previous studies indicate that Trk kinase and Erk kinase activity is needed in both compartments for induction of $b c l w$ transcription (Watson et al., 1999; Watson et al., 2001). This reflects the role of transported signaling endosomes containing activated Trks in these long-range responses (Ginty and Segal, 2002). Addition of the Trk inhibitor K252a or the Erk inhibitor UO126 at either location completely abrogates gene induction of $b c l w$ in cell bodies (Fig. $4 A, D$ ). Similarly, $c$-fos induction is blocked in cell bodies by this intervention (Fig. $4 B, E$ ). Interestingly, the increase in $b c l w$ mRNA in distal axons is also abrogated when $\mathrm{K} 252 \mathrm{a}$ or UO126 is applied to cell bodies (Fig. $4 A, D$ ), despite robust activation of Trk and Erk in distal axons (Fig. 4C,F). This suggests that a Trk-Erk signal from the distal axon must reach the cell body to increase axonal bclw mRNA.

\section{Newly transcribed $b c l w$ mRNA is targeted to axons after distal axon neurotrophin stimulation}

To determine whether transport of $b c l w$ mRNA from cell bodies to distal axons requires transcription of $b c l w$, distal axons were stimulated with neurotrophins while the transcription inhibitor actD was added to the cell body compartment. Addition of actD to cell bodies prevents neurotrophin-dependent increases of $b c l w$ mRNA in axons. In contrast, neurotrophin-dependent increases in axonal $\beta$-actin mRNA are unaffected by actD (Fig. $5 B$ ). Control experiments showed that actD blocks the increased expression of $c$-fos, $b c l w$, and $\beta$-actin in cell bodies, indicating successful inhibition of transcription (Fig. $5 A$ ). Together with the time course studies, these data indicate that $b c l w$ mRNA is regulated differently from $\beta$-actin mRNA and that changes in axonal $b c l w$ mRNA levels depend on neurotrophin-induced transcription, whereas $\beta$-actin mRNA does not.

Previous studies show $\beta$-actin mRNA can be transported to axons from preexisting pools of mRNA in cell bodies without new transcription (Willis et al., 2007). It is possible that transcription of $b c l w$ mRNA replenishes cytoplasmic mRNA pools available for axonal transport. Alternatively, neurotrophins could regulate transcription of $b c l w$ mRNA, such that the new $b c l w$ transcripts are immediately targeted to axons. To follow newly made mRNA from the cell bodies to the distal axons, we pulse-labeled mRNA with 4-thiouridine (Zeiner et al., 2008) during $2 \mathrm{~h}$ of distal axon neurotrophin stimulation and followed the labeled mRNA for an additional $2 \mathrm{~h}$ of distal axon neurotrophin stimulation (Fig. $5 C$ ). The newly transcribed thiouridine-labeled mRNA was isolated from each compartment by biotin-streptavidin pull-down, and the neurotrophin-induced changes in newly transcribed mRNA were assessed by qRT-PCR. As expected, neurotrophin stimulation induces increases in labeled $c$-fos, bclw, and $\beta$-actin mRNA in cell bodies (Fig. 5D). We then analyzed newly transcribed mRNA in distal axons. Neurotrophin stimulation dramatically increases labeled bclw mRNA in axons, indicating that newly made $b c l w$ mRNA is rapidly transported to axons (Fig. $5 E$ ). In contrast, neurotrophin stimulation does not increase labeled, newly transcribed $\beta$-actin mRNA in axons, supporting previous studies showing transport of $\beta$-actin mRNA from preexisting cytoplasmic pools (Fig. 5E). No labeled $c$-fos mRNA is detected in axons. In control experiments, distal axons were stimulated for $4 \mathrm{~h}$ with no 4-thiouridine during the period of stimulation, after $24 \mathrm{~h}$ incubation with 4-thiouridine to label transcripts generated before neurotrophin stimulation (Fig. 5C). In these control experiments, where neurotrophin-induced mRNA is not labeled with 4 -thiouridine, there is no increase in labeled mRNA for $c$-fos, $b c l w$, or $\beta$-actin in cell bodies, and there is no increase in labeled mRNA for $b c l w$ in the axons, verifying the specificity of our assay (Fig. 5D). Thus bclw mRNA represents a new "class" of axonal mRNAs that are transcribed and immediately targeted to axons in response to target-derived neurotrophin stimulation.

\section{Axonal Bclw suppresses the caspase6 apoptotic pathway to prevent axon degeneration}

To address the functional significance of neurotrophin regulation of $b c l w$ mRNA in axons, we asked whether neurotrophins also regulate axonal Bclw protein. In response to $8 \mathrm{~h}$ of neurotrophin stimulation, Bclw protein levels are increased in both cell body and in distal axon compartments (Fig. 6A). To test whether this is the result of local translation of Bclw in the axon, we selec- 

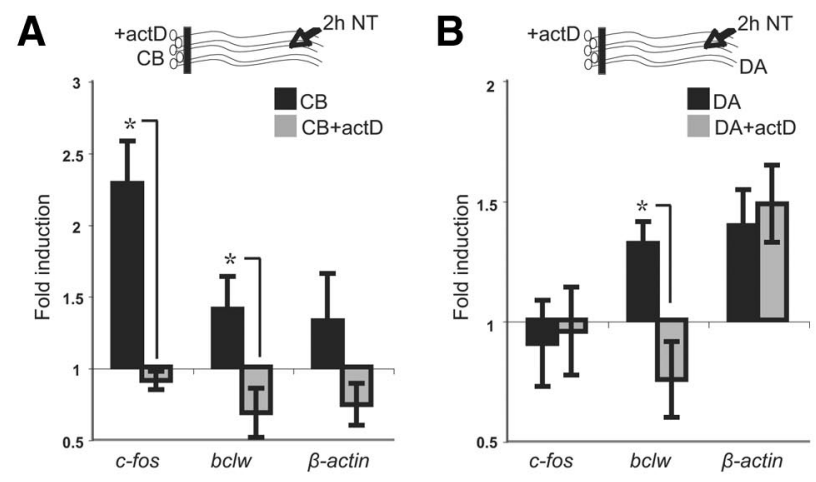

C
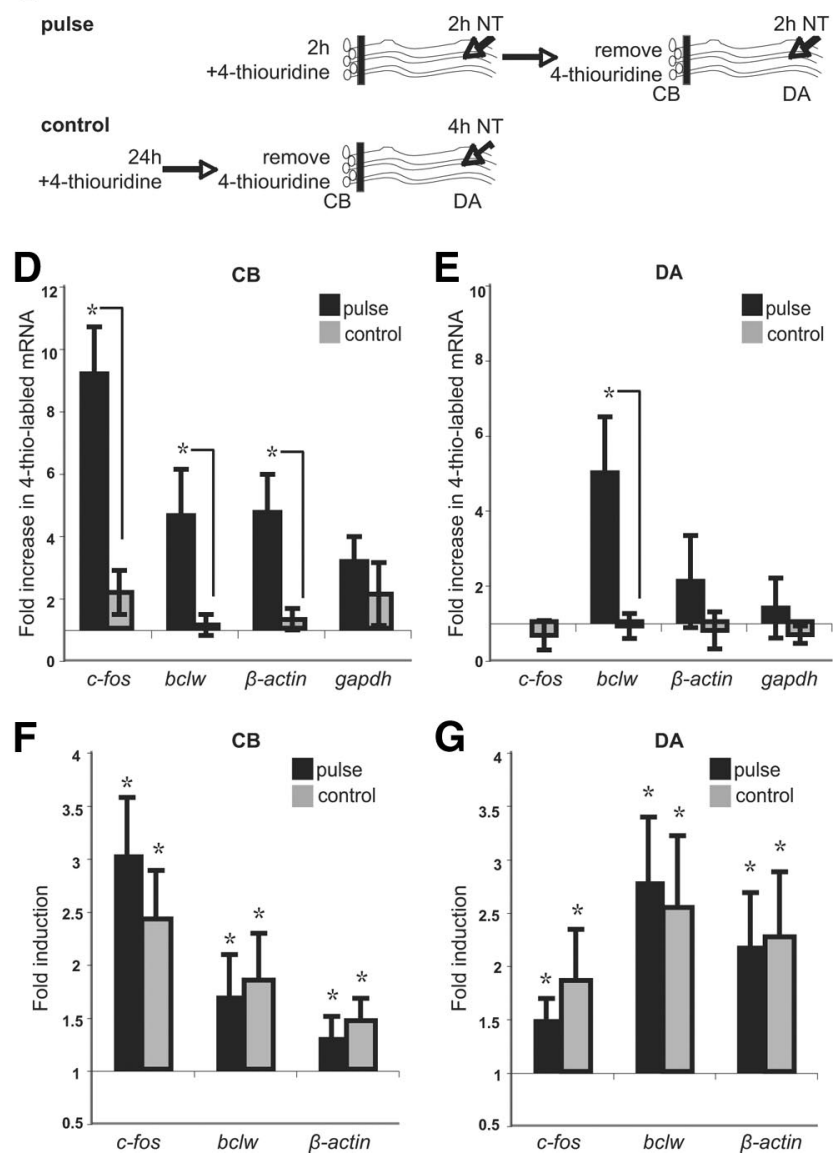

Figure 5. Newly transcribed $b c / w$ mRNA is immediately targeted to distal axons. A, Addition of actD to cell bodies (CB) inhibits transcription of $c-f o s, b c / w$, and $\beta$-actin mRNA in $C B$ in response to distal axon (DA) neurotrophin (NT) stimulation. All data show mean $+\mathrm{SEM} .{ }^{*} p<$ 0.05 (Student's t test); $n=6 . \boldsymbol{B}$, Addition of actD to CB blocks bclw mRNA increase in distal axons (DA). ${ }^{*} p<0.05$ (Student's $t$ test); $n=6$.C, To label new mRNA, 4-thiouridine was added to CB during $2 \mathrm{~h}$ of DA NT stimulation and removed for a further $2 \mathrm{~h}$ DA NT stimulation. In control experiments, 4-thiouridine was added for $24 \mathrm{~h}$ and removed before $4 \mathrm{~h} \mathrm{DA}$ stimulation. $\boldsymbol{D}$, Fold increase in newly transcribed $c$-fos, bclw, and $\beta$-actin mRNA in cell bodies. Levels of newly transcribed gapdh mRNA levels do not change. ${ }^{*} p<0.05$ (Student's $t$ test); $n=5$. $\boldsymbol{E}$, Fold increase in newly transcribed $b c / w$ mRNA in distal axons. ${ }^{*} p<0.05$ (Student's t test); $n=5 . \boldsymbol{F}$, Total mRNA levels of $c-$ fos, $b c / w$, and $\beta$-actin in $C B$ are upregulated in pulse and control experiments. G, Total mRNA levels of $c$-fos, bclw, and $\beta$-actin in DA are upregulated in pulse and control experiments. ${ }^{*} p<0.05$ for a difference from 1 ( $z$ test); $n=5$.

tively inhibited protein synthesis in axons only, or in cell bodies only, and then analyzed Bclw levels. When the translation inhibitor cycloheximide is added to distal axons, neurotrophins do not increase Bclw in axons (Fig. 6B). In contrast, when cycloheximide
A

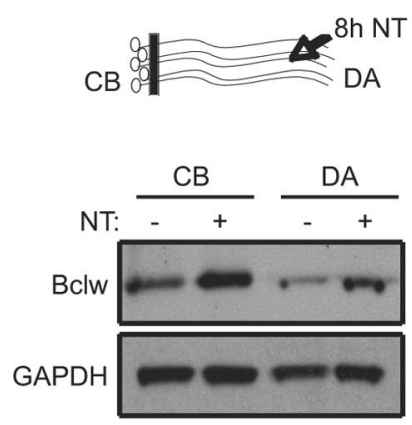

B

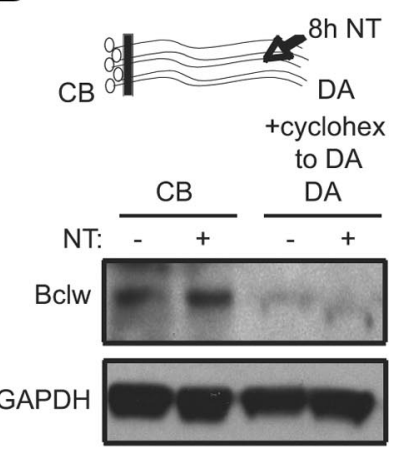

C
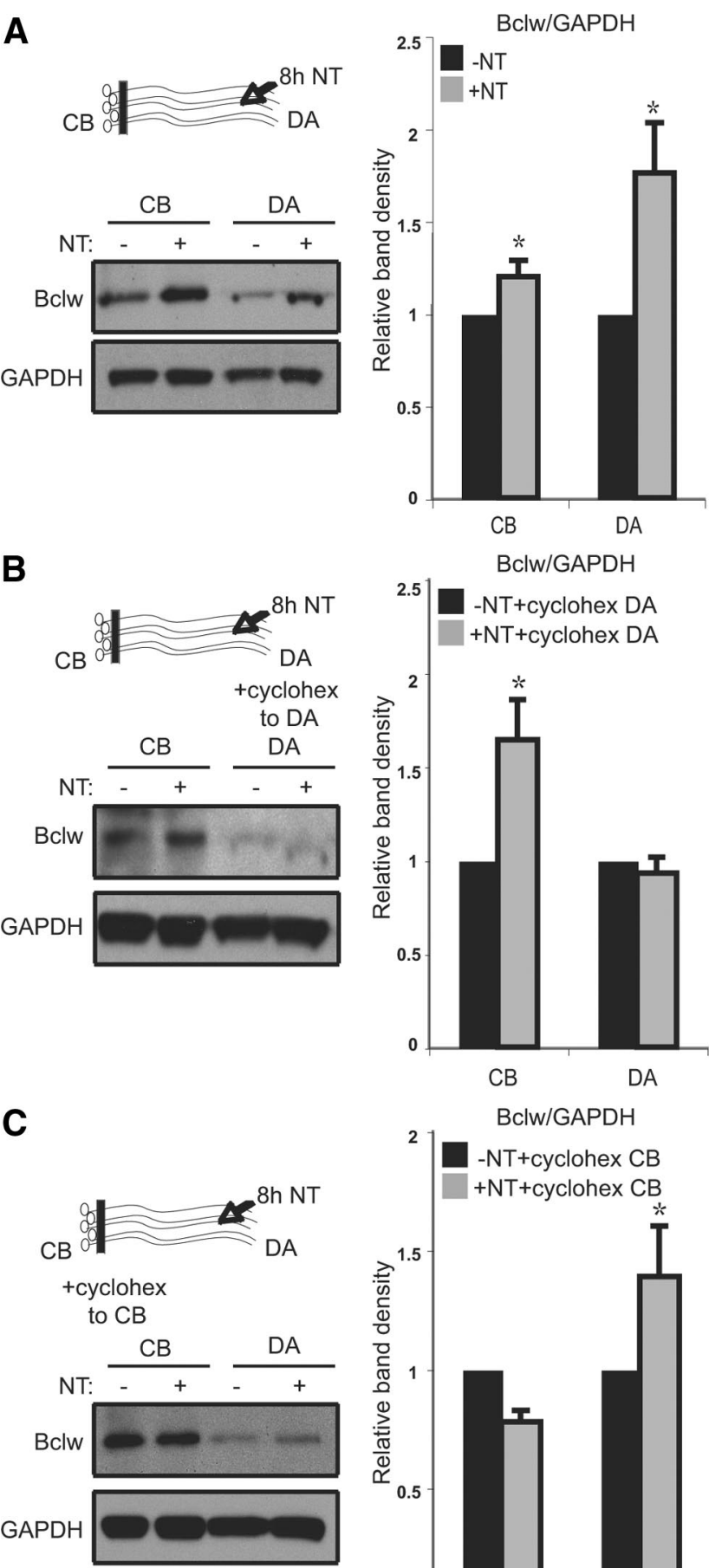

Bclw/GAPDH

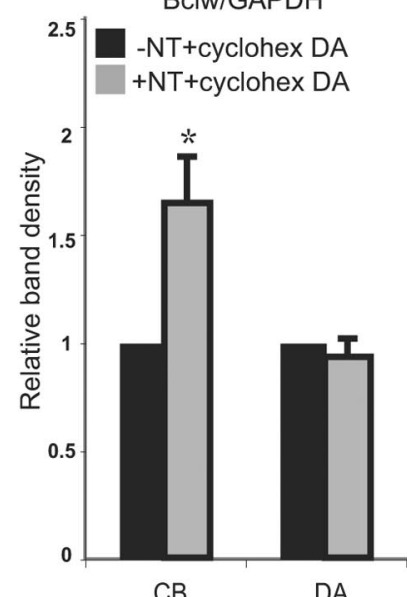

BClw/GAPDH

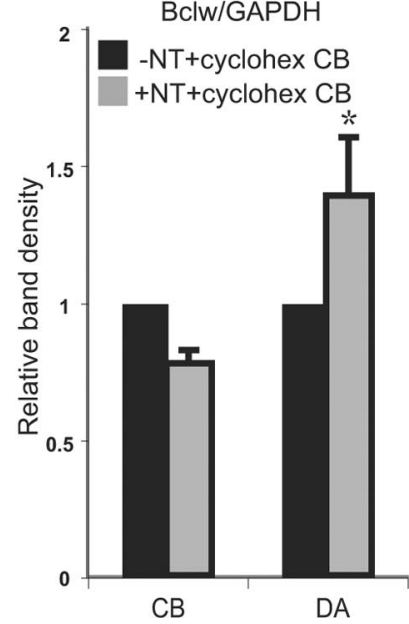

Figure 6. Neurotrophins regulate local translation of $B c l w$ in distal axons. $A$, Western blot analysis and quantification of Bclw in cell body (CB) and distal axon (DA) lysate after $8 \mathrm{~h}$ of DA neurotrophin (NT) stimulation. Results represent the mean + SEM normalized to GAPDH; $n=$ 5. $B$, Western blot analysis and quantification of Bclw in CB and DA lysate after $8 \mathrm{~h}$ of DA NT stimulation with cycloheximide $(10 \mathrm{mg} / \mathrm{ml})$ added to DA. Results represent the mean + SEM normalized to GAPDH; $n=3$. C, Western blot analysis and quantification of Bclw in $C B$ and DA lysate after $8 \mathrm{~h}$ of DA NT stimulation with cycloheximide added to $(B$. Results represent the mean + SEM normalized to GAPDH; $n=3 .{ }^{*} p<0.05$ (Student's $t$ test).

is added to cell bodies, neurotrophins still increase axonal Bclw (Fig. $6 \mathrm{C}$ ).Together, these data suggest that neurotrophins regulate Bclw at multiple steps: transcription, transport and perhaps local translation. 
A

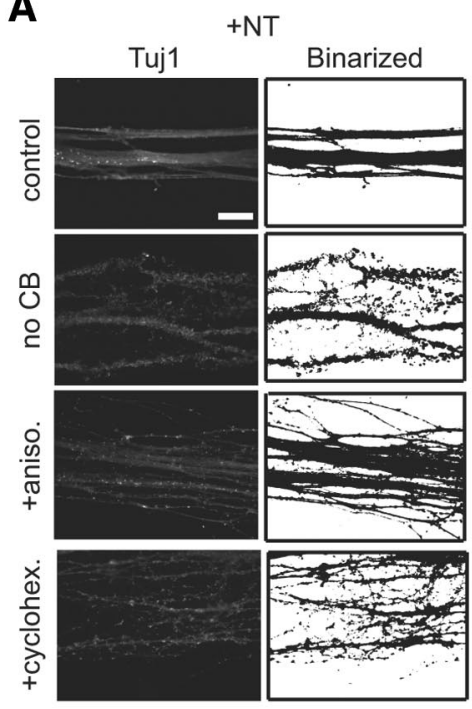

C

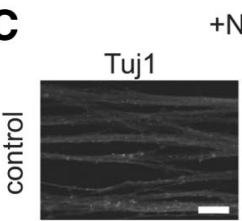

$+\mathrm{NT}$
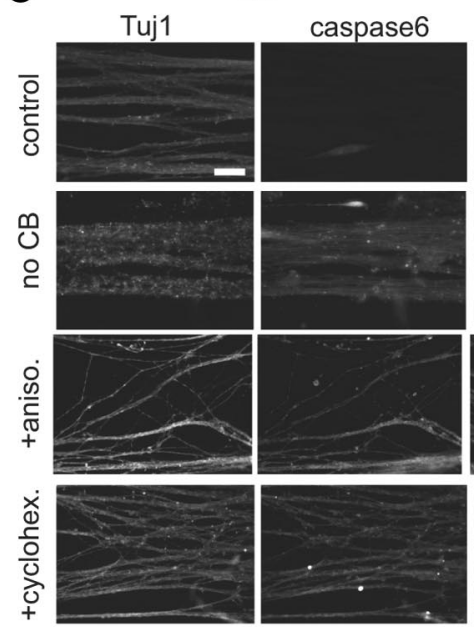

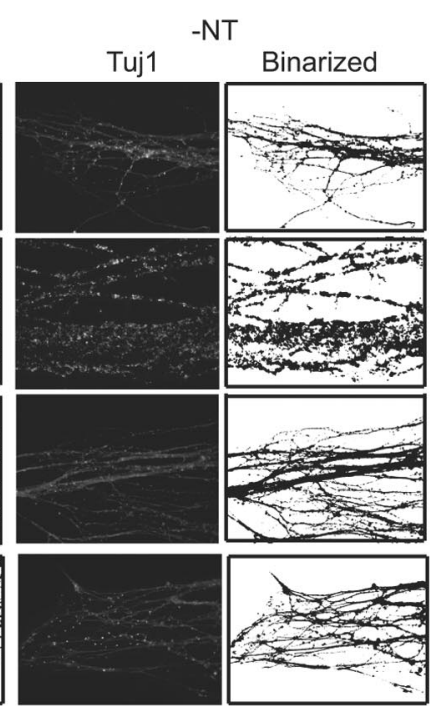

B

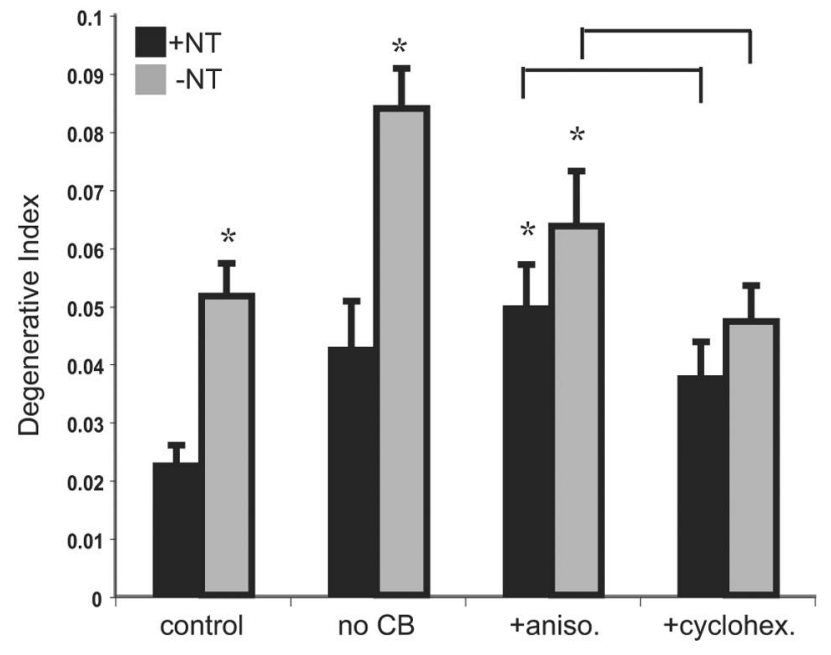

D

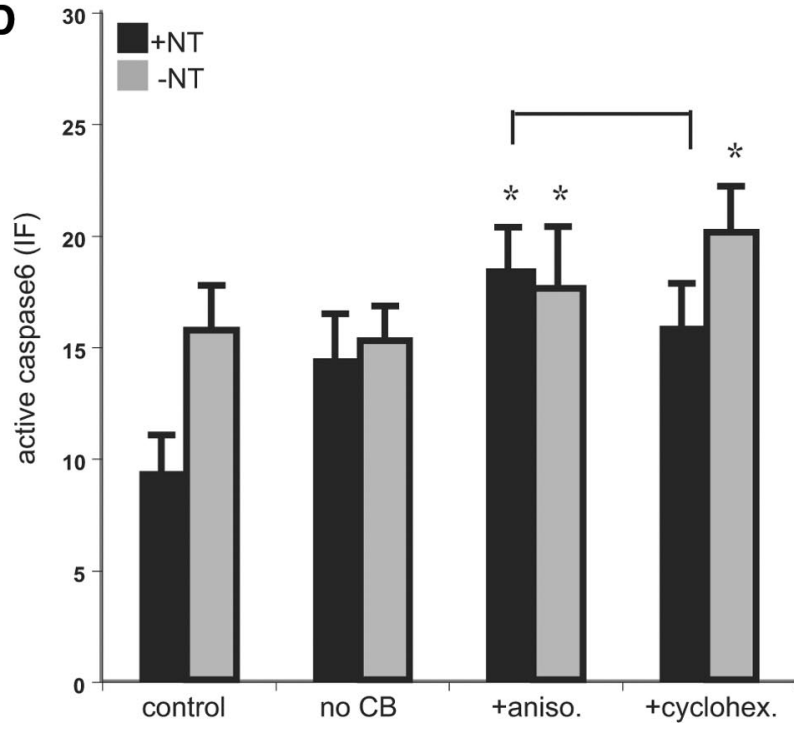

Figure 7. Local translation prevents axon degeneration and caspase6 activation. A,Tuj1-labeled axons in the presence ( + NT; left) and absence ( - NT; right) of neurotrophins. Axons were severed from cell bodies (no $(B)$ or treated with anisomycin or cycloheximide as indicated and deprived of NT for $10 \mathrm{~h}$. Binarized images show fragmented axons defined by the Analyze Particle function in National Institutes of Health ImageJ software. Scale bar, $40 \mu \mathrm{m}$. B, Quantification of axonal degeneration (ratio of area of fragmented axons to total axon area). $p<0.0001$ (one-way ANOVA with Dunnett correction). Results represent the mean + SEM. ${ }^{*} p<0.05$ versus control + NT (one-way ANOVA with Dunnett correction); $n=27-36$ axonal fields from 5 experiments. Quantification for cycloheximide is not significantly different from anisomycin. C, Axons in the presence (+NT; right) and absence ( - NT; left) of neurotrophins stained for activated caspase6. Caspase6 activation is detected in axons severed from cell bodies (no CB) or treated with anisomycin or cycloheximide. Scale bar, $40 \mu \mathrm{m}$. D, Quantification of activated caspase6 in DA shown in C. Results represent the mean + SEM. $p=0.03$ (one-way ANOVA with Dunnett correction). ${ }^{*} p<0.05$ versus control + NT (one-way ANOVA with Dunnett correction); $n=17-24$ axonal fields from 3 experiments. Quantification for cycloheximide is not significantly different from anisomycin.

We previously demonstrated that Bclw is critical for neurotrophin-dependent axonal survival; in cultures from $b c l w^{-1-}$ mice, withdrawal of neurotrophins results in increased axonal degeneration (Courchesne et al., 2011). Therefore, we asked whether manipulations that alter Bclw regulation affect neurotrophin-dependent axonal survival. Withdrawal of neurotrophins from distal axons for $10 \mathrm{~h}$ induces selective axonal degeneration (Fig. $7 A, B$ ). When severed from cell bodies, axonal degeneration is increased. This would be expected because many survival factors are transported from cell bodies, including the Wallerian degeneration slow component, Nmnat (Gilley and Coleman, 2010). Withdrawal of neurotrophins further increases axonal degeneration in isolated axons severed from cell bodies, suggesting that neurotrophins act locally to protect axons from degeneration, per- haps resulting from local translation (Fig. $7 A, B$ ). Indeed, addition of translation inhibitors anisomycin or cycloheximide to axons that remain attached to their cell bodies interrupts the ability of neurotrophins to prevent axon degeneration (Fig. $7 A, B$ ). Neurotrophin withdrawal can activate an APP/DR6/caspase6 pathway to foster axonal degeneration (Nikolaev et al., 2009; Vohra et al., 2010; Simon et al., 2012), and we observed activated caspase6 in degenerating axons after neurotrophin withdrawal (Fig. 7C,D), and inhibition of translation in axons by anisomycin or cycloheximide leads to increased levels of activated caspase6. Together, these data indicate that proteins translated locally in axons prevent activation of caspase 6 and promote axonal viability.

To determine whether Bclw itself works within the axon to promote neurotrophin-dependent axon survival, we used a 
A

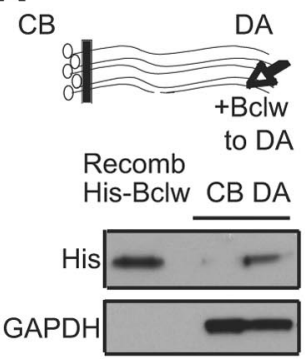

D

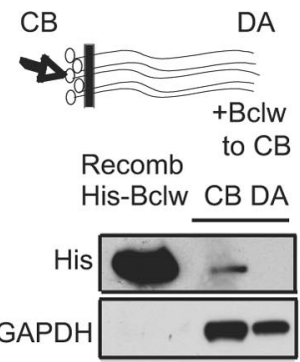

B

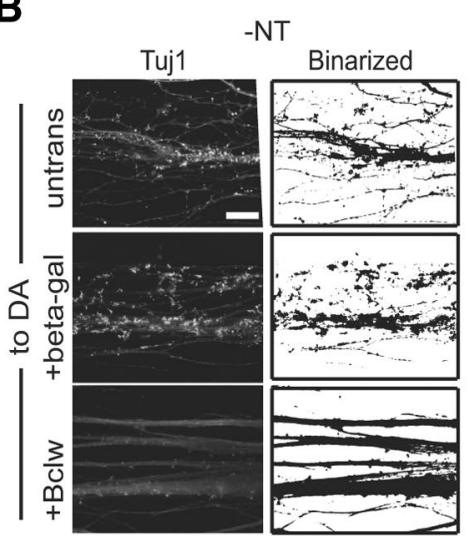

E

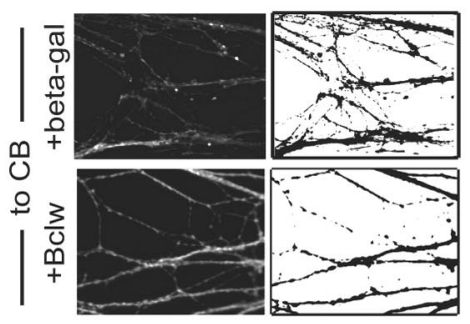

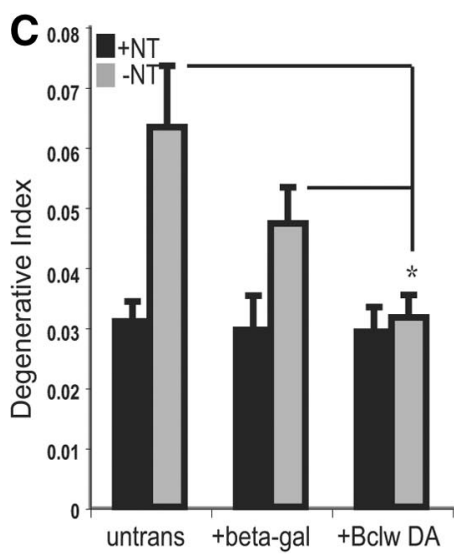

$F_{0.08}$

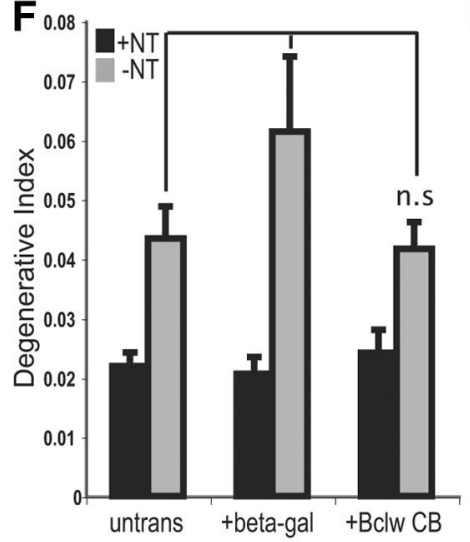

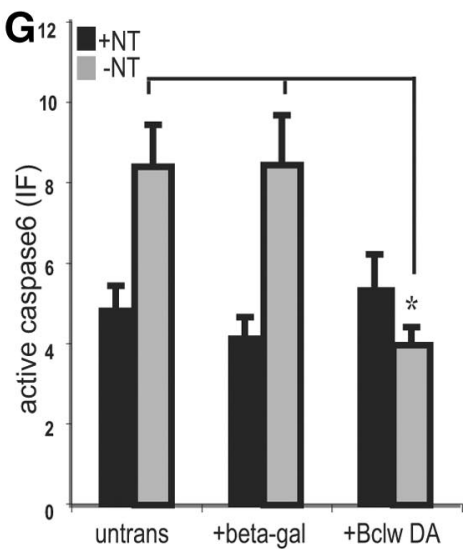

$\mathbf{H}_{10}$

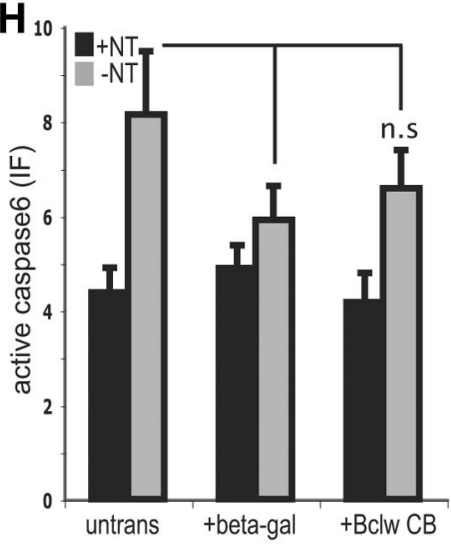

I
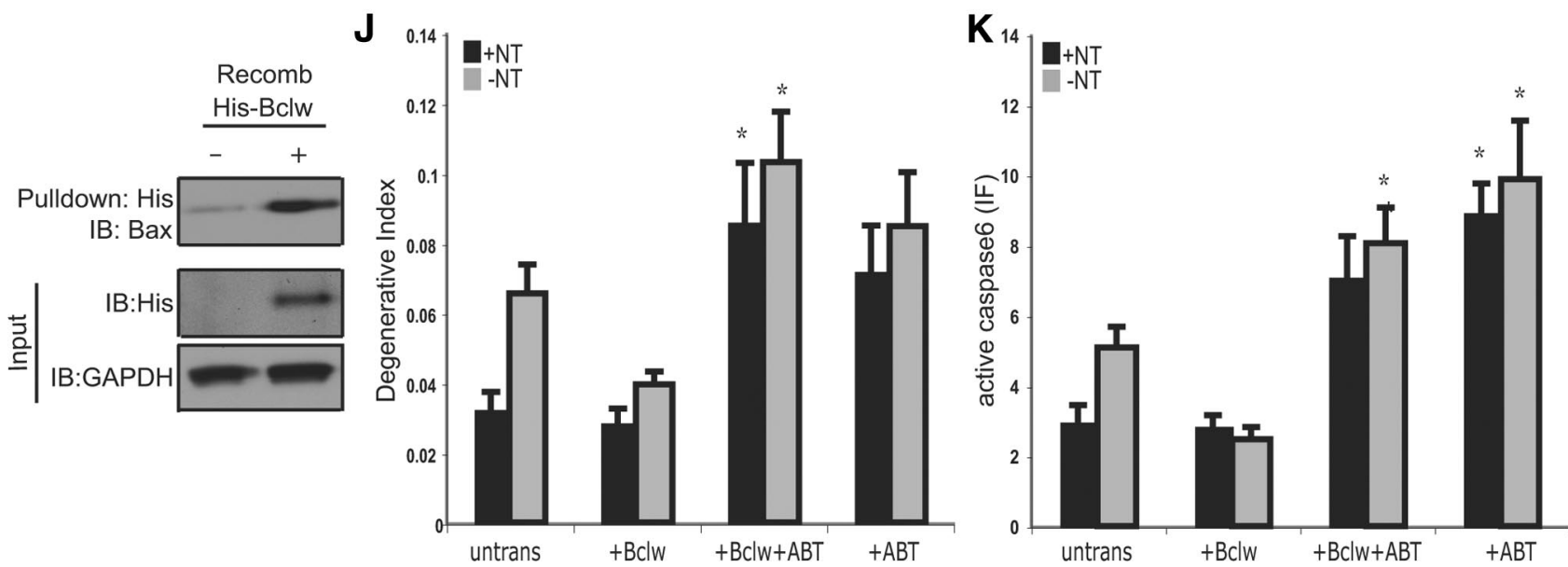

Figure 8. Axonal Bdw binds to Bax and prevents axon degeneration and caspase6 activation. $A$, Western blot for His after selective introduction of His-tagged Bdw protein into distal axons (DA) of DRG neurons grown in compartmented chamber cultures. $\boldsymbol{B}$, Tuj1-labeled axons after introduction of $\beta$-galactosidase ( $\beta$-gal) protein or Bdw protein to DA after $24 \mathrm{~h}$ neurotrophin deprivation ( $-\mathrm{NT}$ ). Scale bar, 40 $\mu \mathrm{m}$. C, Quantification of axonal degeneration after introduction of $\beta$-gal or Bdw protein to DA after removal of NT. All data show mean + SEM. $p=0.0018$ (one-way ANOVA with Bonferroni correction). ${ }^{*} p<$ 0.05 (one-way ANOVA with Bonferroni correction); $n=19$-36axonal fields from 4 experiments. D, Western blotfor His after selective introduction of His-tagged Bdw protein into cell bodies (CB).E, Tuj1-labeled axons after introduction of $\beta$-galactosidase ( $\beta$-gal) protein or Bclw protein to $C B$ after $24 \mathrm{~h}$ neurotrophin deprivation ( $-\mathrm{NT}$ ). Scale bar, $40 \mu \mathrm{m}$. $\boldsymbol{F}$, Quantification of axonal degeneration after introduction of $\beta$-gal or Bdw protein to $C B$ after removal of NT. Statistical analysis by one-way ANOVA. $G, \boldsymbol{H}$, Quantification of activated caspase6 in DA after introduction of $\beta$-gal protein or Bdw protein to DA (G) or CB $(\boldsymbol{H})$, in the presence ( + NT) and absence ( - NT) of neurotrophins. ${ }^{*} p<0.05$ (one-way ANOVA with Bonferroni correction); $n=29-51$ axonal fields from 4 experiments. I, Binding of His-tagged recombinant Bdlw to Bax after His pulldown.J, Quantification of axonal degeneration after addition of ABT-263 to axons with Bdw protein introduced to axons. ${ }^{*} p<0.05$ (one-way ANOVA with Bonferroni correction); $n=10-24$ axonal fields from 3 experiments. $\boldsymbol{K}$, Quantification of activated caspase 6 in DA after addition of ABT-263 to axons with Bclw protein introduced to axons. ${ }^{*} p<0.05$ (one-way ANOVA with Bonferroni correction); $n=8-17$ axonal fields from 3 experiments.

protein transfection system to selectively introduce Bclw into axons. We efficiently and selectively transfected recombinant Bclw-His protein in axonal compartments (Fig. 8A). Introduction of Bclw in axons protects against axonal degeneration caused by removal of neurotrophins, which is readily observed in control untransfected or $\beta$-galactosidase-transfected con- ditions (Fig. $8 B, C$ ). Importantly, Bclw introduced to cell body compartments rather than to axons (Fig. $8 D$ ) cannot prevent axonal degeneration in response to neurotrophin deprivation (Fig. $8 E, F)$. To determine whether Bclw protection of axon viability is associated with reduced caspase 6 activation, we measured activated caspase 6 in axons after Bclw protein was 
introduced. Transfection of Bclw into axons dramatically reduces levels of activated caspase6 (Fig. 8G), whereas transfection of Bclw into cell bodies does not (Fig. $8 H$ ). These results indicate that neurotrophin regulation of local, axonal synthesis of Bclw is critical for supporting axonal survival and that Bclw functions within the axon to suppress the caspase6 apoptotic pathway.

It has been shown that $\mathrm{Bclw}$ binds to the $\mathrm{BH} 3$-binding protein Bax to prevent caspase activation (Yan et al., 2000a; Kim et al., 2012). We found that recombinant Bclw protein introduced into DRG sensory neurons binds to Bax (Fig. 8I). To determine whether Bclw protects axons from degeneration through binding and sequestration of Bax, we applied the $\mathrm{Bcl} 2 / \mathrm{Bcl}-\mathrm{xL} / \mathrm{Bclw}$ inhibitor ABT-263 to axons transfected with recombinant Bclw protein. ABT-263 inhibits binding of $\mathrm{Bcl} 2$ family members to $\mathrm{BH}-3$ domain proteins, including Bax (Tse et al., 2008; Merino et al., 2012), and we see a reduction in recombinant $\mathrm{Bclw}$ protein binding to Bax after treatment with 500 nм ABT-263 (data not shown). Addition of ABT-263 to axons abrogates the ability of recombinant Bclw to prevent axon degeneration and caspase 6 activation after neurotrophin withdrawal (Fig. $8 \mathrm{~J}, \mathrm{~K}$ ). Together, these data indicate that Bclw in axons binds to Bax and thereby suppresses the caspase6 apoptotic pathway.

Previous studies have shown that axons cultured from $b c l w^{-1-}$ mice exhibit increased axon degeneration after neurotrophin withdrawal (Courchesne et al., 2011) (Fig. 9A). We examined whether recombinant Bclw protein introduced into axons deficient for $b c l w$ can rescue the axon degeneration phenotype. Introduction of $\mathrm{Bclw}$ protein into axons of sensory neurons from $b c l w^{-1-}$ mice grown in compartmented chamber cultures protects axons from degeneration after neurotrophin withdrawal (Fig. 9A). We then examined caspase6 activation in sensory axons from $b c l w^{-1-}$ mice and found increased levels of caspase 6 activation after neurotrophin withdrawal compared with $b c l w^{+/+}$axons (Fig. 9B,C). The increase in activated caspase6 is rescued with addition of recombinant Bclw protein to $b c w^{-1-}$ axons (Fig. $9 B, C$ ).

In vivo, Bclw is critical for sustained survival of sensory axons (Courchesne et al., 2011). At 6 months of age, $b_{c l w}{ }^{-/-}$ mice show a progressive nociceptive neuropathy associated with a loss of epidermal innervation and axonal degeneration (Courchesne et al., 2011). We examined activated caspase6 staining in axons of nociceptors that innervate the skin in $b c l w^{+/+}$and $b c l w^{-/-}$mice at 6 months of age. We found significantly elevated levels of activated caspase6 staining in nerve endings stained with Tuj1 in $b c l w^{-/-}$mice (Fig. 9D,E). Nociceptor axons in the epidermis include both peptidergic, TrkA-expressing and nonpeptidergic, TrkA-independent fibers (Silos-Santiago et al., 1995; Molliver and Snider, 1997; Marmigere and Ernfors, 2007). To determine whether degeneration and caspase 6 activation occur in axons of peptidergic neurons in $b \mathrm{clw}^{-/-}$mice, we examined caspase6 staining in substance P-positive fibers. Activated caspase6 staining is increased in subtance P positive-nerve endings in $b c w^{-1-}$ mice (Fig. $9 F, G$ ), demonstrating that in vivo Bclw is critical for maintenance of NGFresponsive, peptidergic axons. Together, these studies suggest that neurotrophins induce increased axonal Bclw through regulated transcription, mRNA transport, and translation, resulting in suppression of the Bax-caspase6 apoptotic cascade and thus preventing axonal degeneration.

\section{Discussion}

The retrograde response gene Bclw is transcriptionally upregulated in response to distal axon neurotrophin stimulation and is critical for viability. Our studies have elucidated a mechanism by which neurotrophin stimulation of distal axons induces transcription of $b c l w$ mRNA and subsequent transport of those newly made transcripts from the cell body to the axon. Furthermore, Bclw protein functions within the axon to inhibit caspase6mediated axonal apoptosis and promote neurotrophindependent axonal survival. We postulate that the scope of Bclw regulation, at the level of transcription, transport, and translation, reflects a mechanism by which signaling cascades are integrated over time, thus promoting axonal maintenance only under conditions of sustained neurotrophin stimulation.

Retrograde neurotrophin signaling has traditionally been thought of as a mechanism by which target-derived neurotrophins communicate to a remote cell body to elicit transcriptional and translational changes required for neuronal survival (Cosker et al., 2008; Chowdary et al., 2012). In this way, only neurons that correctly reach their targets survive and are incorporated into a functional circuit. Because a functional neural connection depends on the maintenance of the axon as well as the cell body, it makes sense that an axon-derived neurotrophin signal would selectively induce expression of genes required for axonal survival. Our data reveal a bidirectional mechanism wherein retrograde neurotrophin signaling from the axon activates a specific transcriptional program of retrograde response genes that in turn increases expression of axon-targeted mRNA and protein critical for axonal maintenance. It seems likely that additional retrograde response genes may also encode mRNAs that localize to the axon and generate protein products whose roles are primarily in the axon.

Intriguingly, it appears that, in vivo, bclw mRNA is predominantly evident in axons that extend to peripheral, neurotrophinexpressing targets, rather than in centrally projecting branches. Indeed, in $b c l w^{-1-}$ mice at 6 months of age, there is considerable loss of peripheral nerves in the epidermis, whereas nerves that extend centrally into the spinal cord show no deficit (Courchesne et al., 2011). Together, these findings suggest that the mechanisms regulating survival and maintenance of centrally and peripherally projecting axons differ from one another. There is evidence in sensory neurons that there are indeed differences between the central and peripheral axons; for example, tyrosinehydroxylase appears to be differentially expressed in peripheral and central axons (Brumovsky et al., 2006). Further studies will be needed to demonstrate whether there is an intrinsic localization element within $b c l w$ that targets the mRNA preferentially to peripheral axons or whether selective targeting of $b c l w$ depends on the local NGF stimulus present in the periphery. Loss of Bclw results in increased activated caspase 6 and degeneration of the peptidergic, NGF-responsive sensory fibers in the epidermis, indicating that Bclw functions to support NGF-dependent axon maintenance in vivo. Other trophic factors in target tissues may similarly regulate Bclw for maintenance of long axons in neuronal subtypes that do not express TrkA.

Regulated transport of mRNA to distal axons in response to neurotrophins requires localization elements often found within the 3'UTR (Andreassi and Riccio, 2009; Donnelly et al., 2010). The best characterized is the $3^{\prime}$ zipcode element in the $3^{\prime}$ UTR of $\beta$-actin mRNA, which contains a 54-nucleotide sequence ("zipcode") responsible for axonal localization (Ross et al., 1997). This is achieved through binding to the mRNA binding protein ZBP1 
A

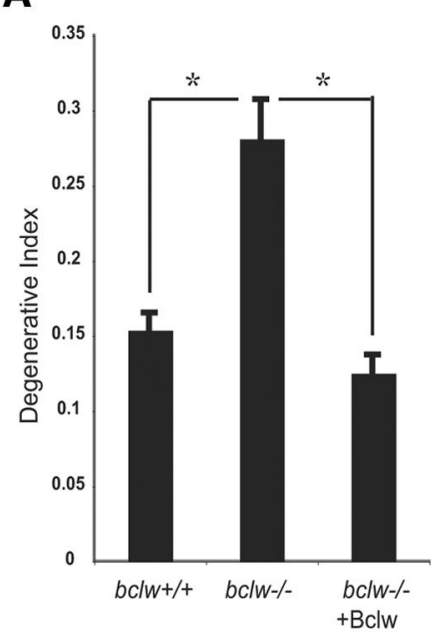

B
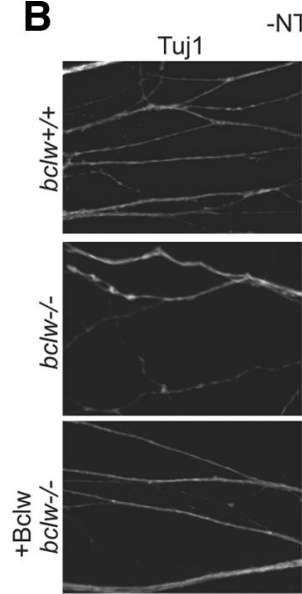

T

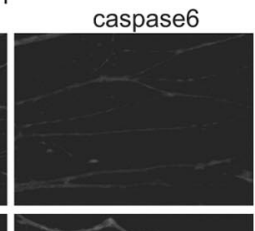

D
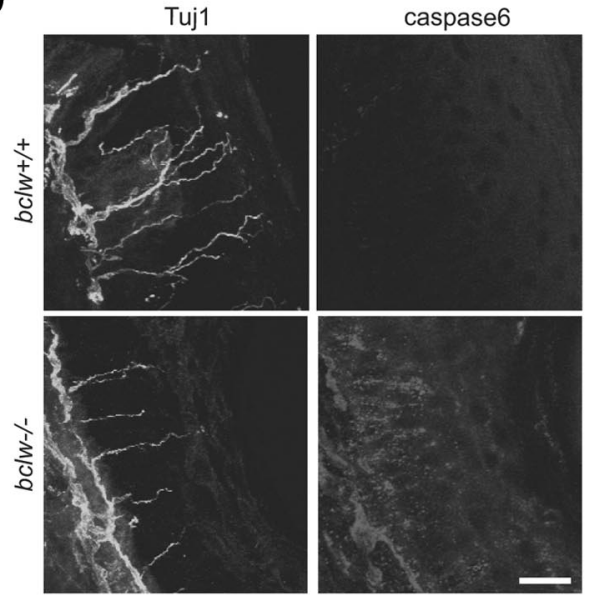

$\mathbf{F}$
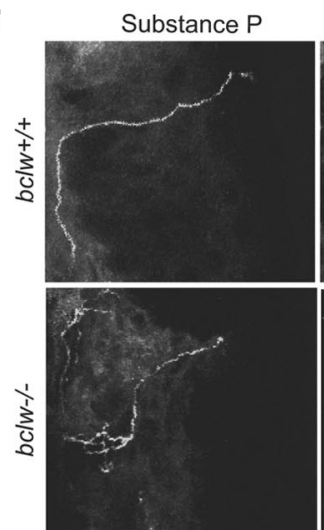

caspase6
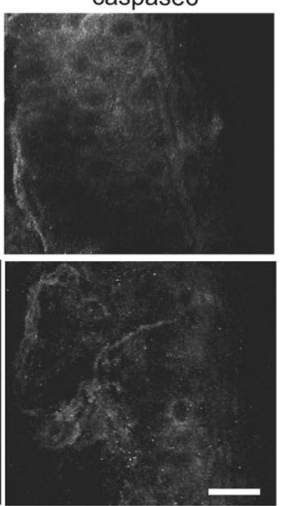
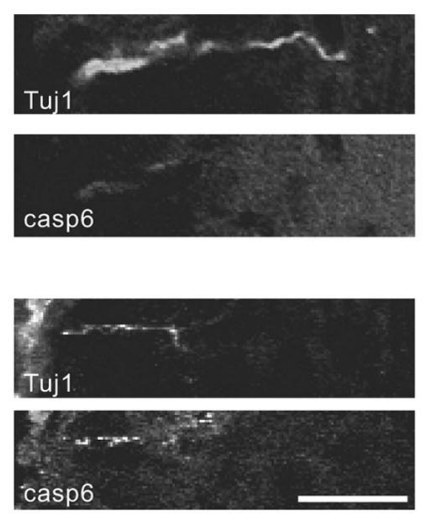

casp6
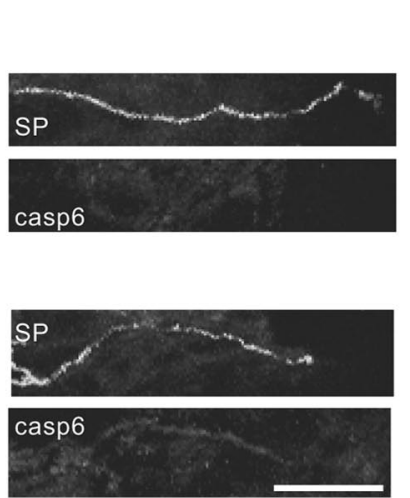

C

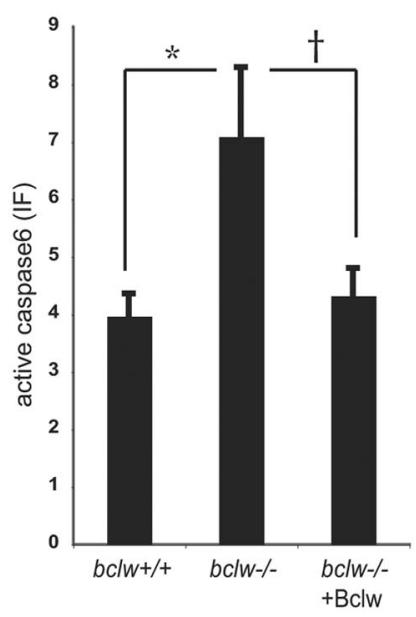

E

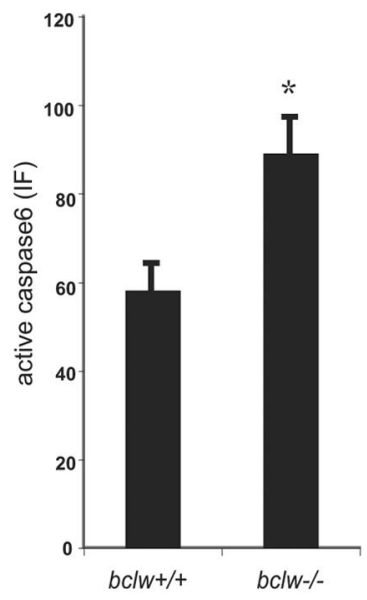

G

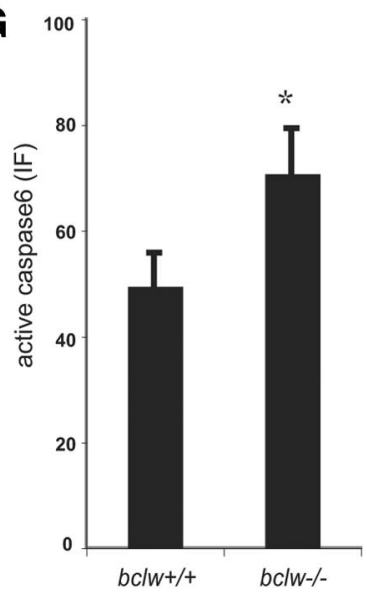

Figure 9. Loss of Bclw leads to increased axon degeneration and caspase6 activation in NGF-responsive axons in vitro and in vivo. $A$, Quantification of axonal degeneration after introduction of Bclw protein to DA of $b c / w^{-1-}$ after removal of NT. Data is represented by the mean + SEM. $p<0.0001$ (one-way ANOVA). ${ }^{*} p<0.05$ (one-way ANOVA). $B$, Tuj1-labeled axons and activated caspase6 staining from $b c / w^{+/+}, b c l w^{-1-}$, and $b c l w^{-/-}$axons transfected with recombinant Bclw protein (+ Bclw) in DRG neurons grown in compartmented chamber cultures in absence of NT. Scale bar, $40 \mu \mathrm{m}$. C, Quantification of activated caspase6 in DA shown in $B . p=0.009$ (ANOVA with Bonferroni correction). ${ }^{*} p<0.05$ (AN0VA with Bonferroni correction). $t p<0.1$ (ANOVA with Bonferroni correction); $n=38$ axonal fields from $3 \mathrm{bclw} w^{+/+}$mice, $n=39$ axonal fields from $3 \mathrm{bclw}{ }^{-1-}$ mice, and $n=28$ axonal fields from $3 \mathrm{bclw}{ }^{-1-}$ mice transfected with recombinant Bclw protein. D, Six-month-old $b c / w^{-1-}$ mice show increased activated caspase6 staining in axons innervating the skin, costained with Tuj1. Scale bars, $50 \mu \mathrm{m}$. E, Quantification of activated caspase6 in axons of 6-month-old $b c / w^{-/-}$and $b c / w^{+/+}$mice. All data show mean + SEM. ${ }^{*} p<0.05$ (Student's $t$ test); $n=$ 3 animals per genotype, $3-5$ sections per animal. $\boldsymbol{F}$, Six-month-old $b \mathrm{clw}^{-1-}$ mice show increased caspase6 staining in substance P-positive fibers innervating the skin. Scale bars, 50 $\mu \mathrm{m}$. G, Quantification of activated caspase6 in substance P-positive axons of 6-month-old $b c / w^{-/-}$and $b c / w^{+/+}$mice. ${ }^{*} p<0.05$ (Student's $t$ test); $n=3$ animals per genotype, 3-5 sections per animal. 
(zipcode binding protein). ZBP1 associates with $\beta$-actin mRNA during transcription (Oleynikov and Singer, 2003; Pan et al., 2007 ) and also during transport to the axons. However, $\beta$-actin transcription and mRNA transport appear to be separately regulated. Thus, $b c l w$ and $\beta$-actin may represent two distinct classes of neurotrophin-regulated mRNA: those whose transcription and transport into axons are coregulated and those whose transport into axons is independent of transcriptional regulation. As $b c l w$ does not contain the same "zipcode" within its 3'UTR as $\beta$-actin, other cis-localization elements and trans-binding mRNA binding proteins are likely to be responsible for targeting $b c l w$ mRNA to axons. The long $2.7 \mathrm{kB} 3^{\prime} \mathrm{UTR}$ of $b c l w$ transcripts may contain several as yet unidentified localization motifs (Andreassi and Riccio, 2009; Cosker and Segal, 2010). Identification of such localization elements and mRNA-binding proteins that interact with $b c l w$ mRNA will give further understanding into how neurotrophins regulate axonal $b c l w$ mRNA levels. It will be interesting to investigate whether mRNAs whose transcription and transport are closely linked might share mRNA-binding proteins and whether this group of mRNAs shares transport mechanisms.

Neurotrophin stimulation increases axonal mRNA for both $b c l w$ and $\beta$-actin, and abundant evidence indicates that this results, at least in part, from mRNA transport (Willis et al., 2007). However, it is not known whether neurotrophin-dependent changes in mRNA stability might also contribute to regulation of axonal mRNAs. Here we measured the half-life of $b c l w$ mRNA and showed that it is not regulated by neurotrophins in DRG neurons. We also measured $\beta$-actin mRNA stability and found that neurotrophins lead to slight changes in stability. These results cannot exclude the possibility that the stability of mRNAs within axons is differentially regulated than elsewhere in the cell. Nonetheless, these data strongly suggest that the neurotrophindependent increase in axonal $b c l w$ and $\beta$-actin mRNA are predominantly the result of regulated mRNA transport.

Like other Bcl-2 family members, Bclw is associated with mitochondria (O'Reilly et al., 2001). A significant proportion of axonally localized mRNAs encode mitochondrial-associated components (Zivraj et al., 2010; Gumy et al., 2011), and local protein synthesis in axons is critical for mitochondrial health (Hillefors et al., 2007). Failure to maintain healthy mitochondria in axons is associated with neurodegenerative diseases and results in axonal degeneration (Court and Coleman, 2012). Mitochondria in $b_{c l w}^{-1-}$ axons show increased length and impaired membrane potential (Courchesne et al., 2011). Abnormal mitochondrial morphology and impaired energy production in $b c l w^{-/-}$mice may contribute to the selective axonal degeneration observed. Intriguingly, laminB2, another mRNA that is locally translated in axons, also associates with the mitochondria (Yoon et al., 2012), and loss of LaminB2 also leads to elongated mitochondria and decreased membrane potential. Although the role for LaminB2, a nuclear-associated intermediate filament protein, at axonal mitochondria is currently unknown, these observations lend further support to the idea that axonal mitochondria require a local supply of new proteins. Local translation of mRNAs, such as bclw or laminB2, may be a mechanism by which healthy mitochondria are maintained in long axons to prevent axonal degeneration. Further work will be needed to definitively demonstrate local translation of Bclw and to show that newly synthesized protein functions to support mitochondrial health in axons.

As a Bcl2 family member, Bclw functions to promote cell survival through inhibition of the apoptotic cascade and so is likely to play a direct role in regulating axonal survival. Recent studies suggest that axonal degeneration after neurotrophin withdrawal is mediated through a distinct apoptotic pathway that requires activation of Bax and caspase 3 and the downstream effector caspase6 (Nikolaev et al., 2009; Vohra et al., 2010; Simon et al., 2012). Bclw is known to bind to Bax and inhibit its mitochondrial pore-forming ability (Yan et al., 2000b; Kim et al., 2012). Here we have shown that Bclw binds to Bax and thereby suppresses activation of caspase 6 and protects axons from degeneration. Thus, Bclw appears to be the axonal antiapoptotic $\mathrm{Bcl} 2$ member critical for neurotrophin-dependent axonal survival. Bax is also required for axon degeneration after axonal injury, which occurs independently of caspase activation (Schoenmann et al., 2010). Thus, Bclw can prevent axon degeneration induced by neurotrophin deprivation and could also play a protective role against axon degeneration after injury.

This work provides new understanding of the mechanisms whereby neurotrophins coordinate signals between distal axons and cell bodies to maintain and preserve connected neurons within a functioning circuit. Our findings suggest that targetderived neurotrophins induce transcription and transport of Bclw to regulate axonal levels of $b c l w$ mRNA and that the function of Bclw protein in axons is critical for suppression of the caspase 6 apopotic cascade and long-term axonal survival. Understanding how Bclw is regulated in developing neurons provides insight into axonal viability during normal development of neuronal circuitry and into axonal degeneration in progressive neurodegenerative disorders.

\section{References}

Andreassi C, Riccio A (2009) To localize or not to localize: mRNA fate is in 3'UTR ends. Trends Cell Biol 19:465-474. CrossRef Medline

Andreassi C, Zimmermann C, Mitter R, Fusco S, Devita S, Saiardi A, Riccio A (2010) An NGF-responsive element targets myo-inositol monophosphatase-1 mRNA to sympathetic neuron axons. Nat Neurosci 13:291-301. CrossRef Medline

Brumovsky P, Villar MJ, Hökfelt T (2006) Tyrosine hydroxylase is expressed in a subpopulation of small dorsal root ganglion neurons in the adult mouse. Exp Neurol 200:153-165. CrossRef Medline

Campenot RB (1982) Development of sympathetic neurons in compartmentalized cultures: II. Local control of neurite survival by nerve growth factor. Dev Biol 93:13-21. CrossRef Medline

Chen CY, Ezzeddine N, Shyu AB (2008) Messenger RNA half-life measurements in mammalian cells. Methods Enzymol 448:335-357. CrossRef Medline

Chowdary PD, Che DL, Cui B (2012) Neurotrophin signaling via longdistance axonal transport. Annu Rev Phys Chem 63:571-594. CrossRef Medline

Cosker KE, Segal RA (2010) The longer U(T)R, the further you go. Nat Neurosci 13:273-275. CrossRef Medline

Cosker KE, Courchesne SL, Segal RA (2008) Action in the axon: generation and transport of signaling endosomes. Curr Opin Neurobiol 18:270-275. CrossRef Medline

Courchesne SL, Karch C, Pazyra-Murphy MF, Segal RA (2011) Sensory neuropathy attributable to loss of Bcl-w. J Neurosci 31:1624-1634. CrossRef Medline

Court FA, Coleman MP (2012) Mitochondria as a central sensor for axonal degenerative stimuli. Trends Neurosci 35:364-372. CrossRef Medline

Danckwardt S, Gantzert AS, Macher-Goeppinger S, Probst HC, Gentzel M, Wilm M, Gröne HJ, Schirmacher P, Hentze MW, Kulozik AE (2011) p38 MAPK controls prothrombin expression by regulated RNA 3'end processing. Mol Cell 41:298-310. CrossRef Medline

Donnelly CJ, Fainzilber M, Twiss JL (2010) Subcellular communication through RNA transport and localized protein synthesis. Traffic 11:14981505. CrossRef Medline

Gilley J, Coleman MP (2010) Endogenous Nmnat2 is an essential survival factor for maintenance of healthy axons. PLoS Biol 8:e1000300. CrossRef Medline 
Ginty DD, Segal RA (2002) Retrograde neurotrophin signaling: Trk-ing along the axon. Curr Opin Neurobiol 12:268-274. CrossRef Medline

Guhaniyogi J, Brewer G (2001) Regulation of mRNA stability in mammalian cells. Gene 265:11-23. CrossRef Medline

Gumy LF, Yeo GS, Tung YC, Zivraj KH, Willis D, Coppola G, Lam BY, Twiss JL, Holt CE, Fawcett JQ (2011) Transcriptome analysis of embryonic and adult sensory axons reveals changes in mRNA repertoire localization. RNA 17:85-98. CrossRef Medline

Hafezparast M, Klocke R, Ruhrberg C, Marquardt A, Ahmad-Annuar A, Bowen S, Lalli G, Witherden AS, Hummerich H, Nicholson S, Morgan PJ, Oozageer R, Priestley JV, Averill S, King VR, Ball S, Peters J, Toda T, Yamamoto A, Hiraoka Y, et al (2003) Mutations in dynein link motor neuron degeneration to defects in retrograde transport. Science 300:808-812. CrossRef Medline

Heerssen HM, Pazyra MF, Segal RA (2004) Dynein motors transport activated Trks to promote survival of target-dependent neurons. Nat Neurosci 7:596-604. CrossRef Medline

Hillefors M, Gioio AE, Mameza MG, Kaplan BB (2007) Axon viability and mitochondrial function are dependent on local protein synthesis in sympathetic neurons. Cell Mol Neurobiol 27:701-716. CrossRef Medline

Kim EM, Kim J, Park JK, Hwang SG, Kim WJ, Lee WJ, Kang SW, Um HD (2012) Bcl-w promotes cell invasion by blocking the invasionsuppressing action of Bax. Cell Signal 24:1163-1172. CrossRef Medline

Leclerc GJ, Leclerc GM, Barredo JC (2002) Real-time RT-PCR analysis of mRNA decay: half-life of $\beta$-actin mRNA in human leukemia CCRF-CEM and Nalm-6 cell lines. Cancer Cell Int 2:1. CrossRef Medline

Luo L, O'Leary DD (2005) Axon retraction and degeneration in development and disease. Annu Rev Neurosci 28:127-156. CrossRef Medline

Marmigère F, Ernfors P (2007) Specification and connectivity of neuronal subtypes in the sensory lineage. Nat Rev Neurosci 8:114-127. CrossRef Medline

Mérino D, Khaw SL, Glaser SP, Anderson DJ, Belmont LD, Wong C, Yue P, Robati M, Phipson B, Fairlie WD, Lee EF, Campbell KJ, Vandenberg CJ, Cory S, Roberts AW, Ludlam MJ, Huang DC, Bouillet P (2012) Bcl-2, $\mathrm{Bcl}-\mathrm{x}(\mathrm{L})$, and $\mathrm{Bcl}-\mathrm{w}$ are not equivalent targets of ABT-737 and navitoclax (ABT-263) in lymphoid and leukemic cells. Blood 119:5807-5816. CrossRef Medline

Molliver DC, Snider WD (1997) Nerve growth factor receptor TrkA is down-regulated during postnatal development by a subset of dorsal root ganglion neurons. J Comp Neurol 381:428-438. CrossRef Medline

Nikolaev A, McLaughlin T, O'Leary DD, Tessier-Lavigne M (2009) APP binds DR6 to trigger axon pruning and neuron death via distinct caspases. Nature 457:981-989. CrossRef Medline

Oleynikov Y, Singer RH (2003) Real-time visualization of ZBP1 association with $\beta$-actin mRNA during transcription and localization. Curr Biol 13: 199-207. CrossRef Medline

O’Reilly LA, Print C, Hausmann G, Moriishi K, Cory S, Huang DC, Strasser A (2001) Tissue expression and subcellular localization of the pro-survival molecule Bcl-w. Cell Death Differ 8:486-494. CrossRef Medline

Pan F, Hüttelmaier S, Singer RH, Gu W (2007) ZBP2 facilitates binding of ZBP1 to $\beta$-actin mRNA during transcription. Mol Cell Biol 27: 8340 -8351. CrossRef Medline

Pazyra-Murphy MF, Segal RA (2008) Preparation and maintenance of dorsal root ganglia neurons in compartmented cultures. J Vis Exp 20.

Pazyra-Murphy MF, Hans A, Courchesne SL, Karch C, Cosker KE, Heerssen HM, Watson FL, Kim T, Greenberg ME, Segal RA (2009) A retrograde neuronal survival response: target-derived neurotrophins regulate MEF2D and bcl-w. J Neurosci 29:6700-6709. CrossRef Medline

Riccio A, Pierchala BA, Ciarallo CL, Ginty DD (1997) An NGF-TrkAmediated retrograde signal to transcription factor CREB in sympathetic neurons. Science 277:1097-1100. CrossRef Medline

Ross AF, Oleynikov Y, Kislauskis EH, Taneja KL, Singer RH (1997) Characterization of a $\beta$-actin mRNA zipcode-binding protein. Mol Cell Biol 17:2158-2165. Medline

Ross AJ, Waymire KG, Moss JE, Parlow AF, Skinner MK, Russell LD, MacGregor GR (1998) Testicular degeneration in Bclw-deficient mice. Nat Genet 18:251-256. CrossRef Medline

Sasaki Y, Vohra BP, Lund FE, Milbrandt J (2009) Nicotinamide mononucleotide adenylyl transferase-mediated axonal protection requires enzymatic activity but not increased levels of neuronal nicotinamide adenine dinucleotide. J Neurosci 29:5525-5535. CrossRef Medline

Schoenmann Z, Assa-Kunik E, Tiomny S, Minis A, Haklai-Topper L, Arama
E, Yaron A (2010) Axonal degeneration is regulated by the apoptotic machinery or a NAD+-sensitive pathway in insects and mammals. J Neurosci 30:6375-6386. CrossRef Medline

Segal RA (2003) Selectivity in neurotrophin signaling: theme and variations. Annu Rev Neurosci 26:299-330. CrossRef Medline

Segal RA, Bhattacharyya A, Rua LA, Alberta JA, Stephens RM, Kaplan DR, Stiles CD (1996) Differential utilization of Trk autophosphorylation sites. J Biol Chem 271:20175-20181. CrossRef Medline

Silos-Santiago I, Molliver DC, Ozaki S, Smeyne RJ, Fagan AM, Barbacid M, Snider WD (1995) Non-TrkA-expressing small DRG neurons are lost in TrkA deficient mice. J Neurosci 15:5929-5942. Medline

Simon DJ, Weimer RM, McLaughlin T, Kallop D, Stanger K, Yang J, O’Leary DD, Hannoush RN, Tessier-Lavigne M (2012) A caspase cascade regulated developmental axon degeneration. J Neurosci 32:17540-17553. CrossRef Medline

Skaper SD (2012) The neurotrophin family of neurotrophic factors: an overview. Methods Mol Biol 846:1-12. CrossRef Medline

Tse C, Shoemaker AR, Adickes J, Anderson MG, Chen J, Jin S, Johnson EF, Marsh KC, Mitten MJ, Nimmer P, Roberts L, Tahir SK, Xiao Y, Yang X, Zhang H, Fesik S, Rosenberg SH, Elmore SW (2008) ABT-263: a potent and orally bioavailable Bcl-2 family inhibitor. Cancer Res 68:3421-3428. CrossRef Medline

Vohra BP, Sasaki Y, Miller BR, Chang J, DiAntonio A, Milbrandt J (2010) Amyloid precursor protein cleavage-dependent and -independent axonal degeneration programs share a common nicotinamide mononucleotide adenylyltransferase 1-sensitive pathway. J Neurosci 30:13729-13738. CrossRef Medline

Watson FL, Heerssen HM, Moheban DB, Lin MZ, Sauvageot CM, Bhattacharyya A, Pomeroy SL, Segal RA (1999) Rapid nuclear responses to targetderived neurotrophins require retrograde transport of ligand-receptor complex. J Neurosci 19:7889-7900. Medline

Watson FL, Heerssen HM, Bhattacharyya A, Klesse L, Lin MZ, Segal RA (2001) Neurotrophins use the Erk5 pathway to mediate a retrograde survival response. Nat Neurosci 4:981-988. CrossRef Medline

Willis DE, van Niekerk EA, Sasaki Y, Mesngon M, Merianda TT, Williams GG, Kendall M, Smith DS, Bassell GJ, Twiss JL (2007) Extracellular stimuli specifically regulate localized levels of individual neuronal mRNAs. J Cell Biol 178:965-980. CrossRef Medline

Willis D, Li KW, Zheng JQ, Chang JH, Smit AB, Kelly T, Merianda TT, Sylvester J, van Minnen J, Twiss JL (2005) Differential transport and local translation of cytoskeletal, injury-response, and neurodegeneration protein mRNAs in axons. J Neurosci 25:778-791. CrossRef Medline

Yan C, Chen J, Chen D, Minami M, Pei W, Yin XM, Simon RP (2000) Overexpression of the cell death suppressor Bcl-w in ischemic brain: implications for a neuroprotective role via the mitochondrial pathway. J Cereb Blood Flow Metab 20:620-630. Medline

Yan W, Samson M, Jégou B, Toppari J (2000) Bcl-w forms complexes with $\mathrm{Bax}$ and Bak, and elevated rations of Bax/Bcl-w and Bak/Bcl-w correspond to spermatogonial and spermatocyte apoptosis in the testis. Mol Endocrinol 14:682-699. CrossRef Medline

Yao J, Sasaki Y, Wen Z, Bassell GJ, Zheng JQ (2006) An essential role for $\beta$-actin mRNA localization and translation in $\mathrm{Ca}^{2+}$-dependent growth cone guidance. Nat Neurosci 9:1265-1273. CrossRef Medline

Yoon BC, Zivraj KH, Holt CE (2009) Local translation and mRNA trafficking in axon pathfinding. Results Probl Cell Differ 48:269-288. CrossRef Medline

Yoon BC, Jung H, Dwivedy A, O'Hare CM, Zivraj KH, Holt CE (2012) Local translation of extranuclear lamin B promotes axon maintenance. Cell 148:752-764. CrossRef Medline

Zeiner GM, Cleary MD, Fouts AE, Meiring CD, Mocarski ES, Boothroyd JC (2008) RNA analysis by biosynthetic tagging using 4-thiouracil and uracil phosphoribosyltransferase. Methods Mol Biol 419:135-146. CrossRef Medline

Zhang HL, Singer RH, Bassell GJ (1999) Neurotrophin regulation of $\beta$-actin mRNA and protein localization within growth cones. J Cell Biol 147:59 70. CrossRef Medline

Zhang HL, Eom T, Oleynikov Y, Shenoy SM, Liebelt DA, Dictenberg JB, Singer RH, Bassell GJ (2001) Neurotrophin-induced transport of a $\beta$-actin mRNP complex increases $\beta$-actin levels and stimulates growth cone motility. Neuron 31:261-275. CrossRef Medline

Zivraj KH, Tung YC, Piper M, Gumy L, Fawcett JW, Yeo GS, Holt CE (2010) Subcellular profiling reveals distinct and developmentally regulated rep- 
ertoire of growth cone mRNAs. J Neurosci 30:15464-15478. CrossRef Medline 